CUADERNOS DE ESTUDIOS GALLEGOS, LX Núm. 126 (enero-diciembre 2013), págs. 255-294

ISSN: 0210-847 X

DOI: $10.3989 /$ ceg.2013.126.07

\title{
EL PROGRAMA ICONOGRÁFICO DEL PRESBITERIO Y CRUCERO DE LA CATEDRAL DE MONDOÑEDO (1769-1773) Y LA RECONSTRUCCIÓN DE LA "PRUEBA PERDIDA"
}

\author{
CARMe LóPez CALDERón
}

Universidad de Santiago de Compostela 


\section{EL PROGRAMA ICONOGRÁFICO DEL PRESBITERIO Y CRUCERO DE LA CATEDRAL DE MONDOÑEDO (1769-1773) Y LA RECONSTRUCCIÓN DE LA "PRUEBA PERDIDA"}

RESUMEN

En el presente artículo abordamos el conjunto escultórico-pictórico del presbiterio y crucero de la Catedral de Santa María de Mondoñedo, ejecutado por José Francisco Terán entre 1769 y 1773. Proponemos su análisis en términos iconográficos, para, una vez identificados los temas, ahondar en sus valores simbólicos de cara a intentar reconstruir el programa — la "prueba perdida"- que justifica su elección. Actuamos así conforme a la función dada por E. Gombrich a la Iconología, la cual asimismo exige buscar el significado concreto que dicha historia ilustrada posee dentro del contexto en que se gesta. De esta manera, consultando fuentes de época, visuales y escritas - destacando las referidas a los frescos de Lucas Jordán en la Iglesia de El Escorial, cuyas concomitancias con el programa mindoniense resultan, cuando menos, llamativas-, y teniendo presentes las enseñanzas contrarreformistas acerca de las prerrogativas de la Deipara y del progreso espiritual del fiel, ofrecemos una lectura en clave de exaltación mariana, cuya finalidad última es recordar a los hombres la mediación que, en aras de su Salvación, la Virgen acomete entre ellos y Dios.

Palabras Clave: Catedral de Mondoñedo, José Francisco Terán, Método iconográfico, Contrarreforma, apología mariana, mediación.

\section{O PROGRAMA ICONOGRÁFICO DO PRESBITERIO E CRUCEIRODA CATEDRAL DE MONDOÑEDO (1769-1773) E A RECONSTRUCIÓN DA “PROBA PERDIDA"}

\section{RESUMo}

No presente artigo abordamos o conxunto escultórico-pictório do presbiterio e cruceiro da Catedral de Santa María de Mondoñedo, executado por José Francisco Terán entre 1769 e 1773. Propomos a súa análise en termos iconográficos, para, unha vez identificados os temas, afondar nos seus valores simbólicos de cara a intentar reconstruír o programa —a "proba perdida" — que xustifica a súa elección. Actuamos así conforme á función dada por E. Gombrich á Iconoloxía, a cal asemade esixe buscar o significado concreto que dita historia ilustrada posúe no contexto no que se xesta. Desta maneira, consultando fontes de época, visuais e escritas destacando as referidas ós frescos de Lucas Jordán na igrexa de O Escorial, cuxas concomitancias co programa mindoniense resultan, cando menos, sorprendentes_, e tendo presentes as ensinanzas contrarreformistas acerca das prerrogativas da Deipara e do progreso espiritual do fiel, ofrecemos unha lectura en clave de exaltación mariana, cuxa finalidade última é lembrar ós homes a mediación que, en aras da súa salvación, a Virxe acomete entre eles e Deus.

Palabras Clave: Catedral de Mondoñedo, José Francisco Terán, Método iconográfico, Contrarreforma, apoloxía mariana, mediación.

\section{THE ICONOGRAPHIC PROGRAM OF THE PRESBYTERY AND TRANSEPT OF MONDOÑEDO CATHEDRAL (1769-1773) AND THE RECONSTRUCTION OF THE "LOST PIECE OF EVIDENCE"}

\section{ABstract}

In this article we deal with the sculptural and pictorial ensemble in the presbytery and transept of the Cathedral of Saint Mary of Mondoñedo, carried out by Francisco José Terán between 1769 and 1773. We propound its analysis from an iconographic point of view so as to, once subjects are identified, go into their symbolic values in depth. With this, our aim is to try to reconstruct the program - the "lost piece of evidence" - that justifies its choice. In doing so, we act according to the function given by E. Gombrich to the Iconology, that also demands to look for the concrete meaning that this illustrated story has within the context in which it appears. Of that way, handling visual and written sources of the period — standing out those referred to the frescoes by Lucas Jordan in the church of The Escorial, whose similarities with the Mondoñedo program are, at least, strinking — and considering the Counter-Reformation teachings about the prerogatives of the Deipara and the spiritual progress of the faithful, we offer an interpretation focused in the Marian exaltation, whose last target is to remind the people the mediation that, in honour of their Redemption, Virgin undertakes between them and God.

KEY WORDS: Cathedral of Mondoñedo, José Francisco Terán, Iconographic Method, Counter-Reformation, Marian apology, Mediation. 
Recibido/Received: 21/11/2012

Aceptado/Accepted: 19/08/2013

E n 1769, el pintor leonés José Francisco Terán ${ }^{1}$ contrata con el cabildo de la catedral de Mondoñedo la realización del retablo que habría de presidir la capilla mayor (Fig. 1), labor que completaría entre 1771 y 1773 ejecutando, primero, las pinturas de los muros y bóveda del presbiterio (Fig. 2) y, segundo, las de la bóveda del crucero $^{2}$ (Fig. 3).

Si bien ya se ha señalado que retablo y pinturas obedecen a una misma iconografía ${ }^{3}$, todavía resta por ofrecer una lectura de conjunto que permita explicar el porqué de todos los temas representados, siendo este el objetivo del presente artículo. Para ello, proponemos un análisis en términos iconográficos, identificando en primer lugar las figuras y escenas seleccionadas, para, a continuación, profundizar en los contenidos que encierran, siendo estos valores simbólicos los que justifican las relaciones existentes entre ellas. De esta manera, comprobaremos cómo en todos los casos existe un leitmotiv: la referencia, más o menos explícita, a la Madre de Dios, siendo, pues, la exaltación mariana el eje rector

\footnotetext{
1 Pocos datos poseemos sobre este autor, nacido en la parroquia leonesa de San Martín. Sabemos que a la altura de 1763 está trabajando para la catedral de León, desde donde se traslada a Astorga para ejecutar el Monumento del Jueves Santo. En esta misma ciudad firmaría el 4 de agosto de 1766 el contrato para pintar y dorar la capilla mayor de la Catedral de Lugo, siendo esta empresa la última que acomete antes de iniciar la de Mondoñedo (Enrique Fernández CastiñeIras, "El lenguaje pictórico mariano de la capilla mayor de Mondoñedo", Adaxe, 7 (1991), págs. 43-44; Enrique Fernández Castiñeiras y Juan Manuel Monterroso Montero, "Ecclesia, Domus et Mullier. Fundamentos iconográficos para el estudio de las pinturas de José de Terán en la catedral de Mondoñedo", en Francisco Singul (dir.), Rudesindus. La tierra y el templo, Santiago de Compostela, Xunta de Galicia, Consellería de Innovación e Industria, 2007, pág. 188).

2 El retablo se contrata el 8 de enero de 1769 por la cantidad de 44000 reales de vellón, disponiendo José Francisco Terán para su ejecución de la ayuda de los escultores Agustín Baamonde, Juan Antonio González Riobó y José Antonio de Castro. Las pinturas supondrían un nuevo abono de 52.000 reales, firmándose a mediados de 1772 la ejecución de las de la bóveda del transepto (Enrique Fernández Castiñeiras y Juan Manuel Monterroso Montero, "Ecclesia, Domus..., págs. 188 y 198).

3 Enrique Fernández Castiñeiras y Juan Manuel Monterroso Montero, "Ecclesia, Domus..., pág. 188.
} 


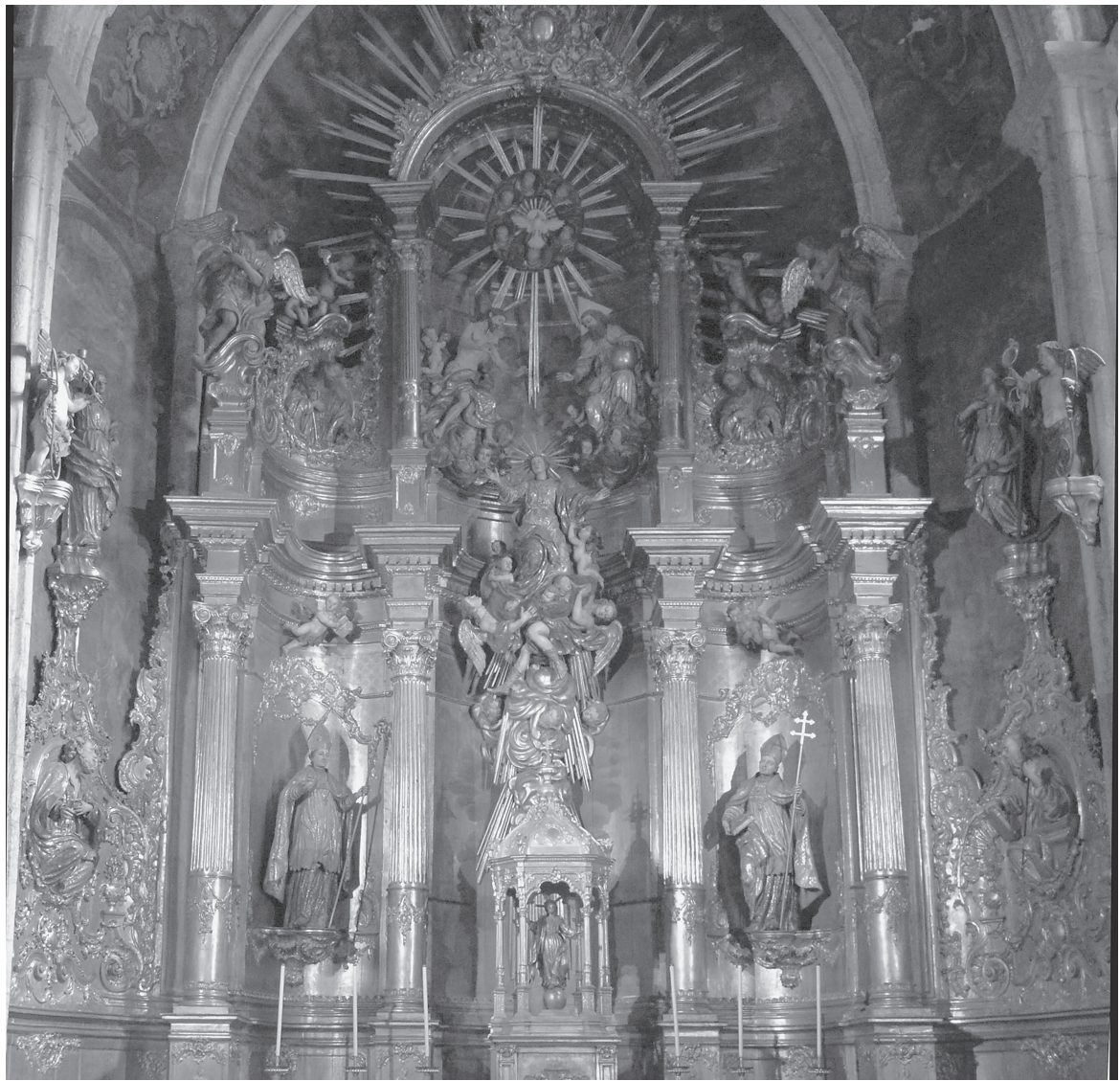

Fig. 1

Retablo mayor de la Catedral de Mondoñedo. José Francisco Terán, Agustín Baamonde, Juan Antonio González Riobó y José Antonio de Castro (1769).

que unifica un programa, que, en última instancia, amonesta al fiel sobre su comportamiento ${ }^{4}$.

\section{LOS TEMAS TALLADOS: EL RETABLO}

El retablo se estructura en dos cuerpos y tres calles, de las cuales la central alberga la Asunción de María a los cielos, en donde es recibida por la Santísima

${ }^{4}$ Consecuentemente, nuestro objetivo último es ofrecer una lectura iconológica del conjunto, en el sentido dado por Gombrich al término: "a grandes rasgos, entendemos por iconología, desde los estudios pioneros de Panofsky, la reconstrucción de un programa más que la identificación de un texto concreto" (Ernest Gombrich, Imágenes simbólicas, Madrid, Alianza editorial, 1983, pág. 18). 


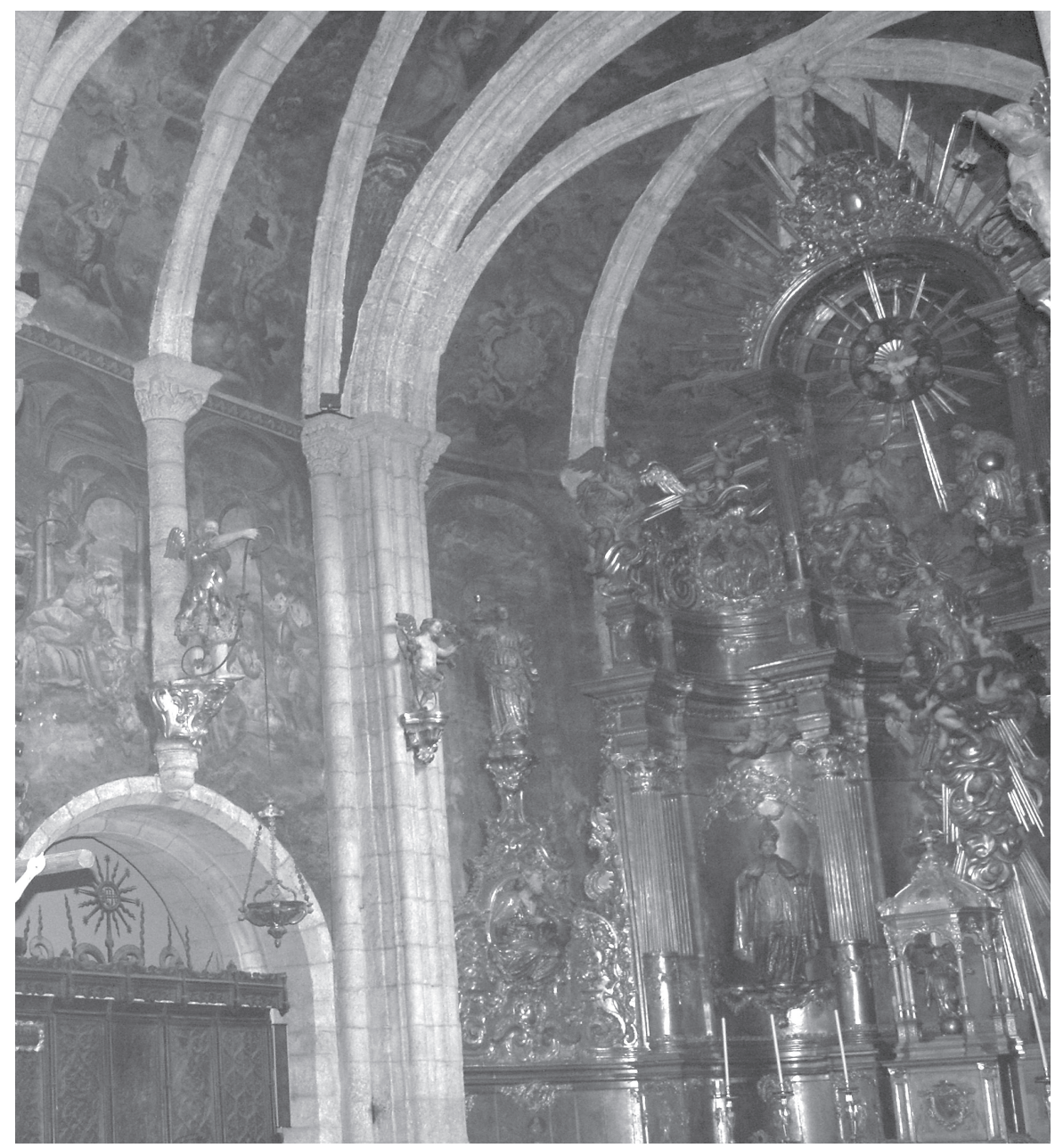

Fig. 2

Pinturas de la bóveda y muros del presbiterio de la Catedral de Mondoñedo. José Francisco Terán (1771-1773).

Trinidad. A los lados se disponen sendos medallones (Fig. 4): a la izquierda, en el lado de la Epístola, sus padres, san Joaquín y Santa Ana; a la derecha, san José portando la vara florida: su atributo habitual que refiere su carácter de esposo virginal $^{5}$. Debajo, e identificados mediante cartelas, encontramos a san Rosendo y San Martín de Dumio, ambos estrechamente vinculados a la diócesis min-

\footnotetext{
5 Louis RÉAU, Iconografia del arte cristiano. Iconografía de los santos $G-O$, tomo 2, vol. 4, Barcelona, Ediciones del Serbal, 1997, pág. 162.
} 


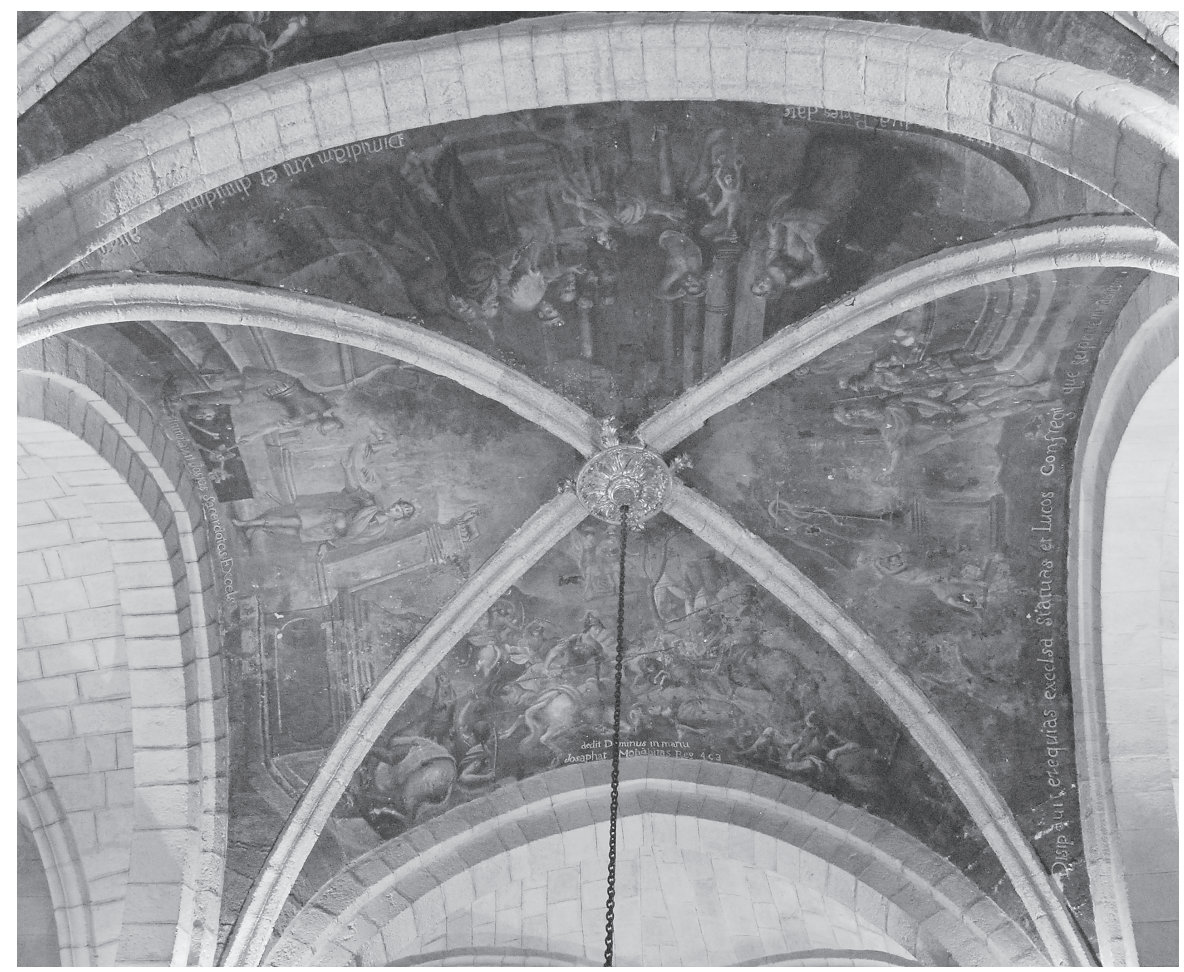

Fig. 3

Pinturas de la bóveda del crucero de la Catedral de Mondoñedo. José Francisco Terán (1772-1773).
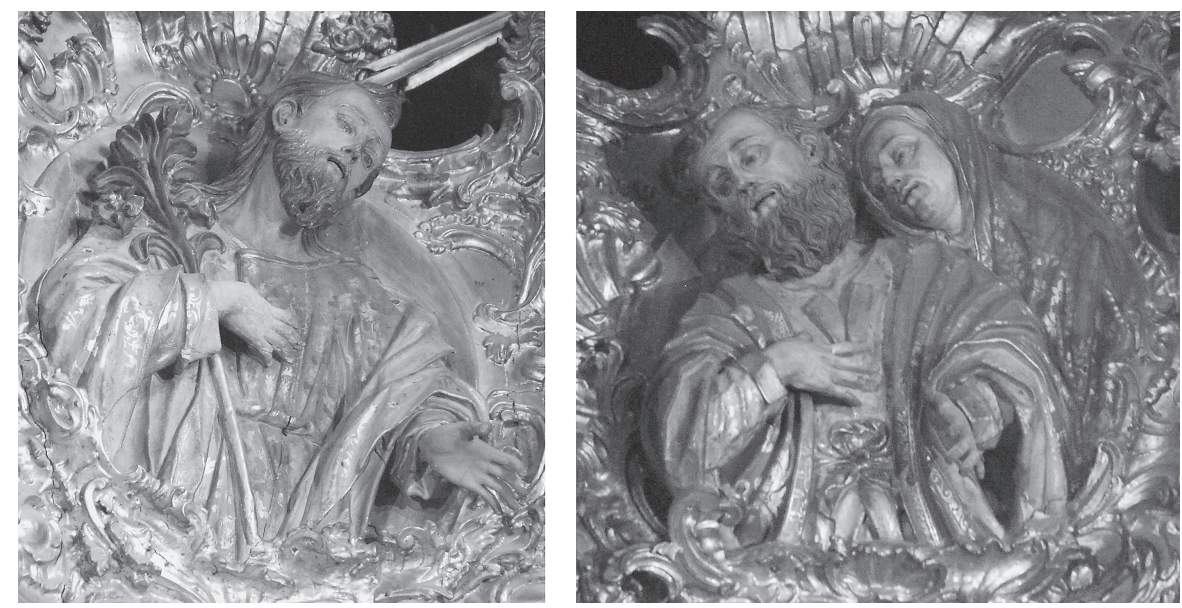

Fig. 4

Medallones del retablo mayor: san José (izquierda) y san Joaquín y santa Ana (derecha). 

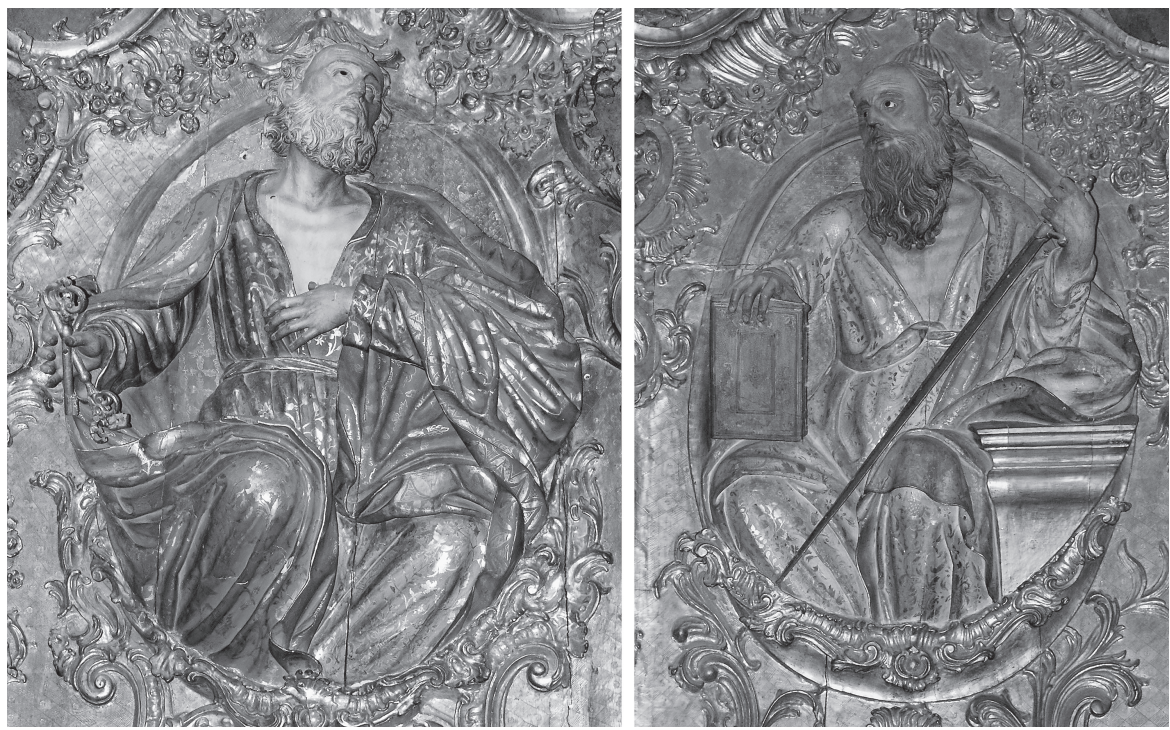

Fig. 5

Medallones de las alas del retablo mayor: san Pedro (izquierda) y san Pablo (derecha).

doniense $^{6}$ y cuyas valiosas reliquias la catedral había conseguido poco tiempo atrás ${ }^{7}$.

El retablo se prolonga lateralmente por medio de dos alas, en donde dos nuevos medallones dan cabida a san Pedro y san Pablo (Fig. 5), cuya presencia es muy habitual en representación del conjunto de apóstoles y en relación con el sometimiento de la Iglesia a Roma. Precisamente, el primero de ellos, además de

${ }_{6}$ En el año 866, el obispo de Dumio, Sabarico, huye a causa de las invasiones árabes y se refugia en el Monasterio de San Martín de Mondoñedo, recibiendo del rey Alfonso III la jurisdicción del territorio, privado hasta la fecha de pastores espirituales. Por su parte, san Rosendo, fundador del Monasterio de Celanova, se forma y es obispo en Mondoñedo, convirtiéndose luego en el patrón principal de la diócesis (Sebastián Santos San Cristóbal, La catedral de Mondoñedo, Lugo, Servicio de Publicaciones de la Diputación Provincial, 1989, págs. 3-4).

7 En 1614, en tiempos del obispo Alfonso Mesía de Tovar, se traslada desde Celanova una reliquia de san Rosendo, mientras que ya en el primer tercio del siglo XVIII el obispo Muñoz y Salcedo consigue llevar desde Braga otra reliquia de san Martín de Dumio (José Manuel García IgLesias, "La capilla mayor y el coro de la catedral de Mondoñedo a partir de 1769", Letras Galegas en Deusto. Dez anos de estudios galegos, 1991-2001, Cátedra de Estudios Galegos, Facultad de Filosofía y Letras, Universidad de Deusto, 2001, pág. 193).

8 Según García Iglesias, estas alas laterales se deben posiblemente a una ampliación posterior, acometida entre 1771 y 1773, lo que justificaría el siguiente dato documental: El Cabildo le dio, además, de gratificación 7.529 reales y 14 maravedís, más 6.300 reales por lo que añadió al retablo... respecto de las trazas que él había formado... (José Manuel García IgLesias, "La capilla mayor...", págs. 192 y 194). 

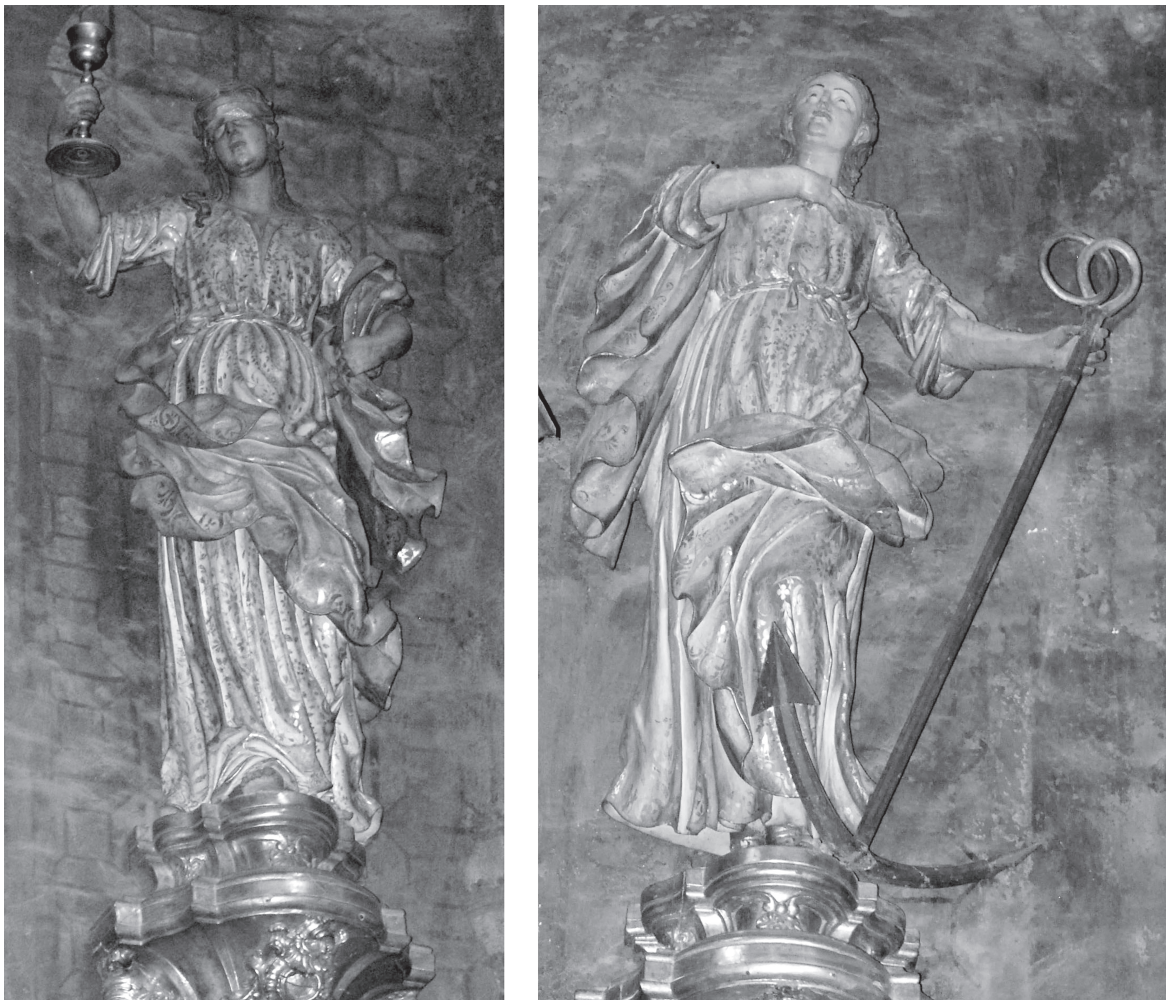

Fig. 6

Virtudes teologales sobre las alas del retablo mayor: Fe (izquierda) y Esperanza (derecha).

portar las dos llaves, en significación de su poder de absolución y excomunión, completa su iconografía mediante la tiara y la cruz de triple travesaño que aluden a su dignidad papal ${ }^{9}$. San Pablo se representa sujetando la espada de su martirio y un libro, por las cartas del Nuevo Testamento ${ }^{10}$, al tiempo que el escudo que sostiene el ángel recuerda que él es el Vas electionis ${ }^{11}$.

Encima de san Pedro se dispone la Fe, mientras que sobre san Pablo figura la Esperanza, indicándonos justamente san Juan de la Cruz que San Pedro no halló otro mayor amparo que ella [la Fe] para librarse de él [Demonio] quando dixo: Resístanle firmes en la fe y que a la Esperança llama San Pablo Yelmo de

\footnotetext{
9 Louis RÉAU, Iconografia del arte cristiano. Iconografía de los santos $P-Z$, tomo 2, vol. 5, Barcelona, Ediciones del Serbal, 1998, págs. 50-51.

${ }^{10}$ Louis RéAu, Iconografia del arte cristiano. Iconografía de los santos P-Z..., págs. 10-11.

${ }^{11}$ Ve, porque vaso escogido me es éste, para que lleve mi Nombre en presencia de los gentiles, y de reyes, y de los hijos de Israel (Hechos, 9:15).
} 
salud $^{12}$. Ambas virtudes teologales responden a su iconografía habitual (Fig. 6): la primera, sostiene un cáliz y lleva los ojos vendados ${ }^{13}$; la segunda, porta un ancla y está vestida con manto verde ${ }^{14}$. La Caridad, aún cuando no aparece personificada, queda perfectamente significada a través del Santísimo Sacramento que alberga el tabernáculo ${ }^{15}$; no en vano, no existe mayor ejemplo de Caritas que el sacrificio que Cristo voluntariamente acepta para redimir a los hombres ${ }^{16}$.

En el basamento del retablo conviven dos grupos de figuras femeninas: uno se corresponde con sibilas y otro con alegorías. Las sibilas son adivinas que surgen en la Antigüedad en el Mediterráneo Oriental. A raíz de la universalización que experimenta el cristianismo, las sibilas se convierten en profetas paganas; en palabras de Clemente Alejandrino: assí como Dios nuestro Señor les dio a los Judios Profetas que les diessen noticia de la venida del Hijo de Dios al mundo, assí les dio a los Griegos y Gentiles Profetisas que les diessen esta misma noticia $^{17}$. De esta manera, los teólogos han ido estableciendo paralelismos entre sus oráculos y diversos acontecimientos de la vida de Cristo y María, siendo estos vaticinios los que explican sus atributos ${ }^{18}$.

${ }^{12}$ San Juan de la Cruz, Obras espirituales que encaminan a una alma, a la más perfecta unión con Dios, en transformación de amor, Sevilla, por Francisco de Leesdael, 1703, pág. 263.

${ }^{13}$ Con la otra mano sostiene por fin el Cáliz, símbolo de la Fe, en el que se fundan todas nuestras esperanzas y la verdadera finalidad de nuestros deseos, por cuanto la Fe consiste en una firme creencia, ajena a toda duda, por la que confiamos con entera certidumbre en la existencia de Dios, así como en su divino Poder y Providencia ("Fe Católica", Cesare Ripa, Iconología, tomo 1, Madrid, Ediciones Akal, 1987, pág. 403); "Elect. Dime, Desiderio, ¿qué significa el estar la Fe con los ojos vendados, como yo la he visto?/ Desid. Porque la Fe, para ser como debe, ha de estar ciega, no ha de buscar razones para creer las verdades, porque éstas son más elevadas de lo que alcanza la luz de la razón humana" (Jaime BARón y ARín, Luz de la fe y de la Ley, Barcelona, Imprenta de Teresa Piferrer, 1735, págs. 35-36).

${ }^{14} \mathrm{La}$ asociación del ancla con la esperanza se pone en relación con el versículo de san Pablo: Tenemos como ancla del alma, una esperanza segura y firme, y que penetra hasta detrás del velo (Hebreos, 6:19).

${ }^{15}$ El expositor actual data de 1914, hecho en Mondoñedo según diseño de D. Ramón Martínez Insua y dorado por D. Manuel Cortiñas (Sebastián SANTOS SAN CRISTóbal, La catedral..., pág. 39). En el momento en que Terán ejecuta el retablo, existía un tabernáculo de plata realizado por Pedro Garrido en 1705, cuya descripción puede encontrarse en Enrique CAL PARDO, "Sacristía y Custodia de la Catedral basílica de Mondoñedo", Estudios Mindonienses, 3 (1987), págs. 556-567.

16 José Manuel LóPEZ VÁzQUEZ: "Los retablos mayores: homilía contrarreformista y propaganda monástica", en Opus Monasticorum. Patrimonio, Arte, Historia y Orden, Santiago de Compostela, Xunta de Galicia, Consellería de Cultura, 2005, pág. 222. Otros autores han visto la referencia a la Caridad en Mondoñedo a través de la paloma del Espíritu Santo que, como integrante de la Trinidad, corona el retablo, o de la propia figura de la Virgen que lo preside (José Manuel García IgLESIAS, "La capilla mayor...”, pág. 194).

${ }^{17}$ Baltasar Porreño, Oráculos de las doçe Sibilas. Profetisas de Christo nro. Señor entre los Gentiles, Cuenca, por Domingo de la Yglesia, 1621, fol. 1r.

${ }^{18}$ Louis RÉAU, Iconografia de la Biblia. Antiguo Testamento, tomo 1, vol. 1, Barcelona, Ediciones del Serbal, 1996, págs. 477-487. 

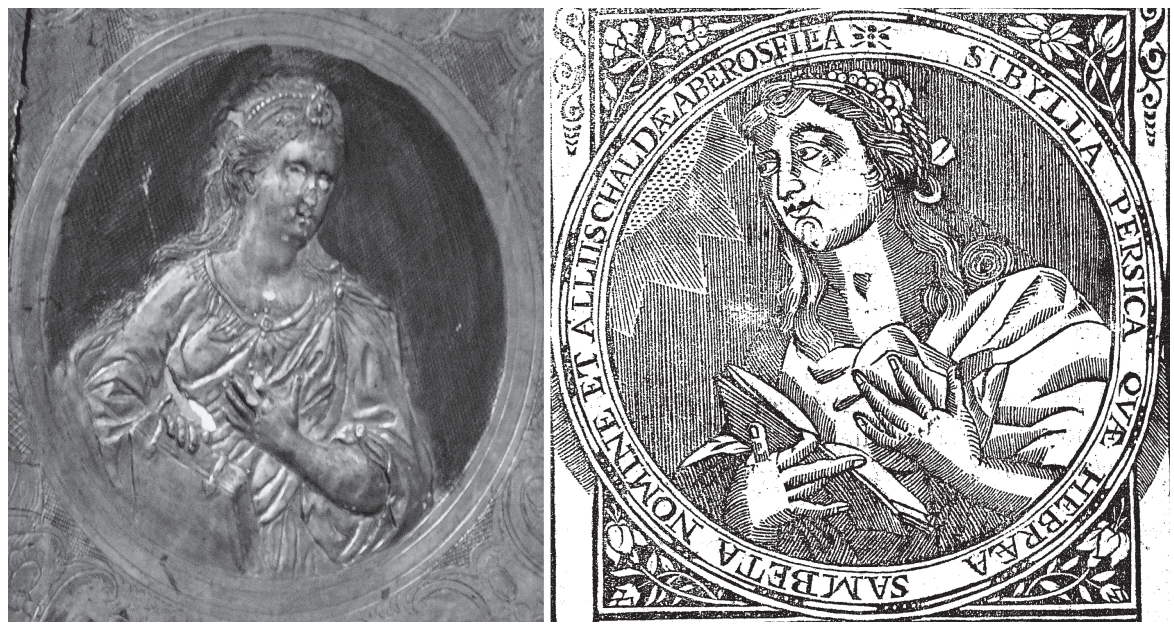

Fig. 7

Sibila Pérsica. Basamento del retablo mayor (izquierda) y xilografía tomada de Oráculos de las doce Sibilas (Baltasar Porreño, 1621) (derecha).
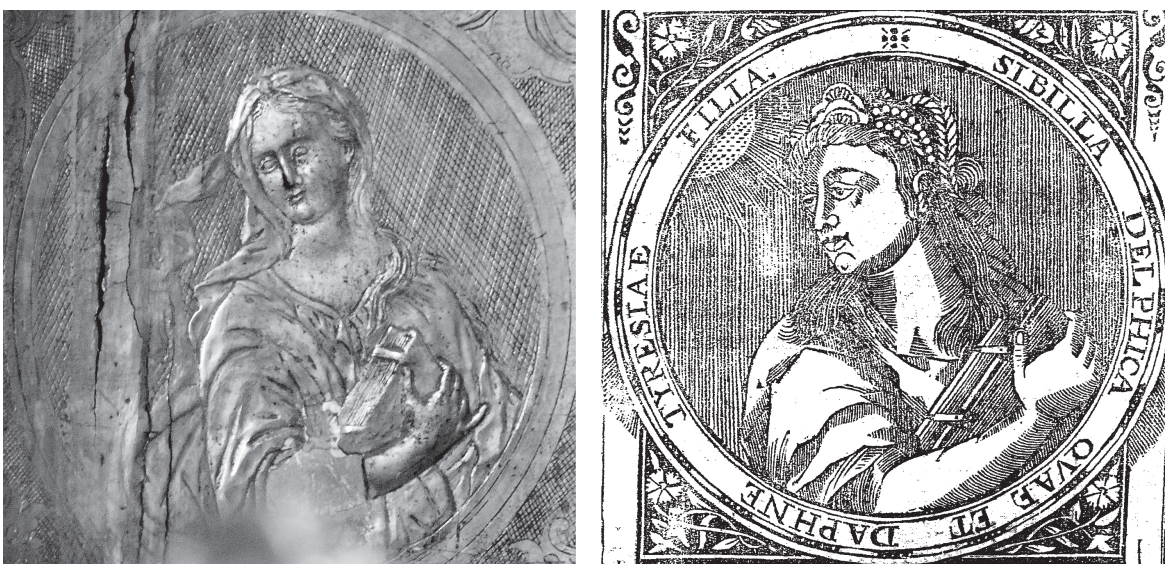

Fig. 8

Sibila Délfica. Basamento del retablo mayor (izquierda) y xilografía tomada de Oráculos de las doce Sibilas (Baltasar Porreño, 1621) (derecha).

No obstante, ni sus atributos son siempre los mismos, ni su iconografía ha permanecido inmutable, sino que se ha ido modificando a lo largo del tiempo. En el caso de las sibilas de Mondoñedo, su concepción resulta bastante próxima a la propuesta de Crispin van der Passe el Viejo, que es, junto a la de Claude Vignon, la que mayor influencia ejerce en los siglos XVII y XVIII. De hecho, los graba- 

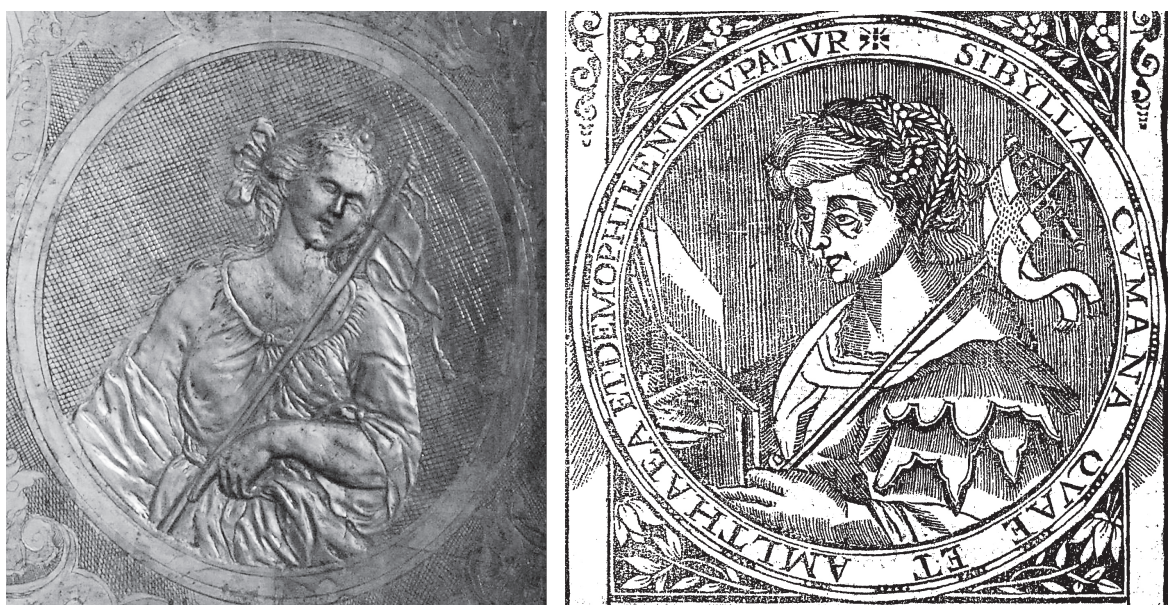

Fig. 9

Sibila Cumana. Basamento del retablo mayor (izquierda) y xilografía tomada de Oráculos de las doce Sibilas (Baltasar Porreño, 1621) (derecha).

dos del primero sirven de fuente directa para las xilografías de la obra de Baltasar Porreño titulada Oráculos de las doce Sibilas, cuya repercusión fue notable en todo el ámbito Hispano ${ }^{19}$; así lo evidencia, por ejemplo, la serie ejecutada por el pintor novohispano Pedro Sandoval en la segunda mitad del siglo XVIII y actualmente conservada en la llamada Sala de las Sibilas del Palacio de Minería en México ${ }^{20}$. Por nuestra parte, apoyándonos en las explicaciones de Porreño, podemos comprender mejor los atributos de las sibilas mindonienses, cuya identificación se nos facilita al constar su nombre inciso en la zona superior.

Así, de izquierda a derecha encontramos, primero, a la sibila Pérsica (Fig. 7), representada con el libro de sus profecías y con la mano yzquierda puesta sobre el pecho, para dar a entender la seguridad de sus oráculos, y la certeza que prometía al mundo por ellos, de la venida del Salvador. Además, parece más anciana que las otras, lo cual puede venir dado porque Sillio Italico llamóla vieja, assí por lo mucho que alcançó, pues dezimos que los viejos saben mucho, como por su mucha antigüedad, y también por lo mucho que vivió, como se a dicho ${ }^{21}$.

En segundo lugar, a la Délfica (Fig. 8), pintada

\footnotetext{
${ }_{19}$ José Miguel Morales Folguera, Las sibilas en el arte de la Edad Moderna, Europa mediterránea y Nueva España, Málaga, Servicio de Publicaciones de la Universidad de Málaga, 2007, págs. 482-485 y 495-497.

${ }^{20}$ Santiago Sebastián, Iconografía e Iconología del arte novohispano, México, Grupo Azabache, 1992, págs.118-129.

${ }^{21}$ Baltasar Porreño, Oráculos..., fols. 7v.-12r.
} 

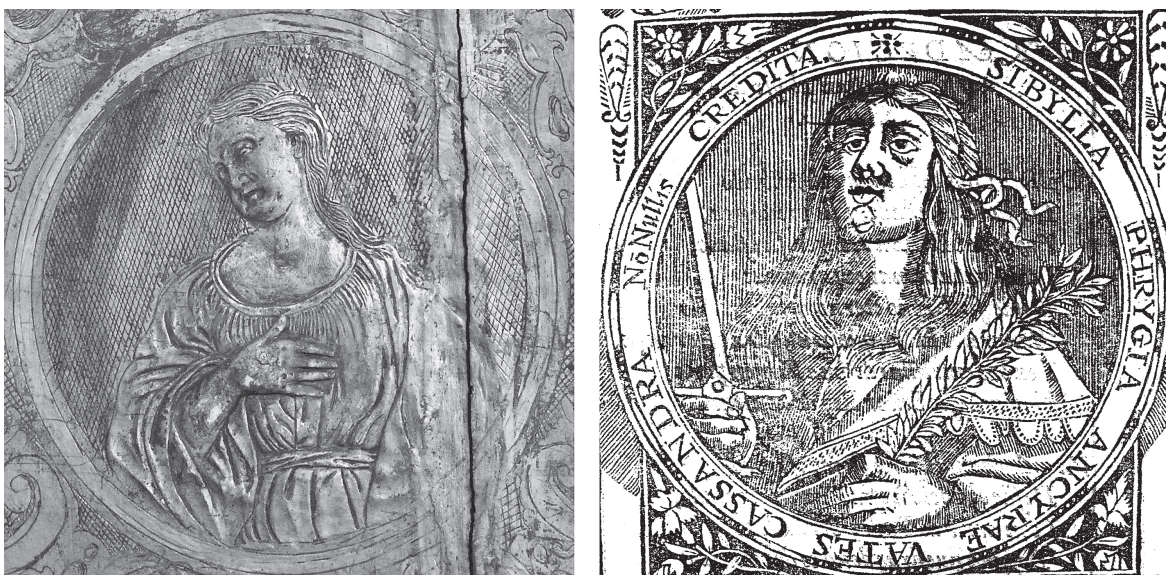

Fig. 10

Sibila Frigia. Basamento del retablo mayor (izquierda) y xilografía tomada de Oráculos de las doce Sibilas (Baltasar Porreño, 1621) (derecha).

con el libro cerrado, porque profetizó del libro de los mysterios de Dios [...] miran [las hojas del libro] acia el cielo, para darnos a entender que el mysterio altíssimo de su profezía [...] sólo le penetrava Dios, y de sola su sabiduría podía salir esta traza, y este hecho tan azañoso 22 .

En tercer lugar, a la Cumana (Fig. 9), sosteniendo el labaro con Cruz, para significar que Christo nuestro Señor, de quien hablavan sus versos fue nuestro Capitán, y con su cruz que es nuestro guión se alcançó la vitoria ${ }^{23}$. Finalmente, la Sibila Frigia (Fig. 10) no porta atributo alguno ${ }^{24}$, aunque, al igual que las anteriores, aparece identificada por la inscripción grabada en la parte superior del óvalo.

Por lo que respecta al segundo grupo de figuras femeninas (Fig. 11), se trata de alegorías de difícil identificación, dado que se acompañan de un único elemento a través del cual se puede significar distintos conceptos. En cualquier caso, atendiendo al mensaje que, en nuestra opinión y como luego justificaremos, se pretende transmitir y echando mano de la Iconología de Césare Ripa, parece que a la izquierda, sosteniendo un cordero, se dispone la Humildad: una

\footnotetext{
${ }^{22}$ Baltasar Porreño, Oráculos..., fols.18r.-23r.

${ }^{23}$ Baltasar Porreño, Oráculos..., fols.23v.-29r.

${ }^{24}$ Según Baltasar Porreño, pintan a esta sibila con "una espada en la mano derecha, y un ramo de laurel" (Oráculos..., fols.46r.-51r.).
} 

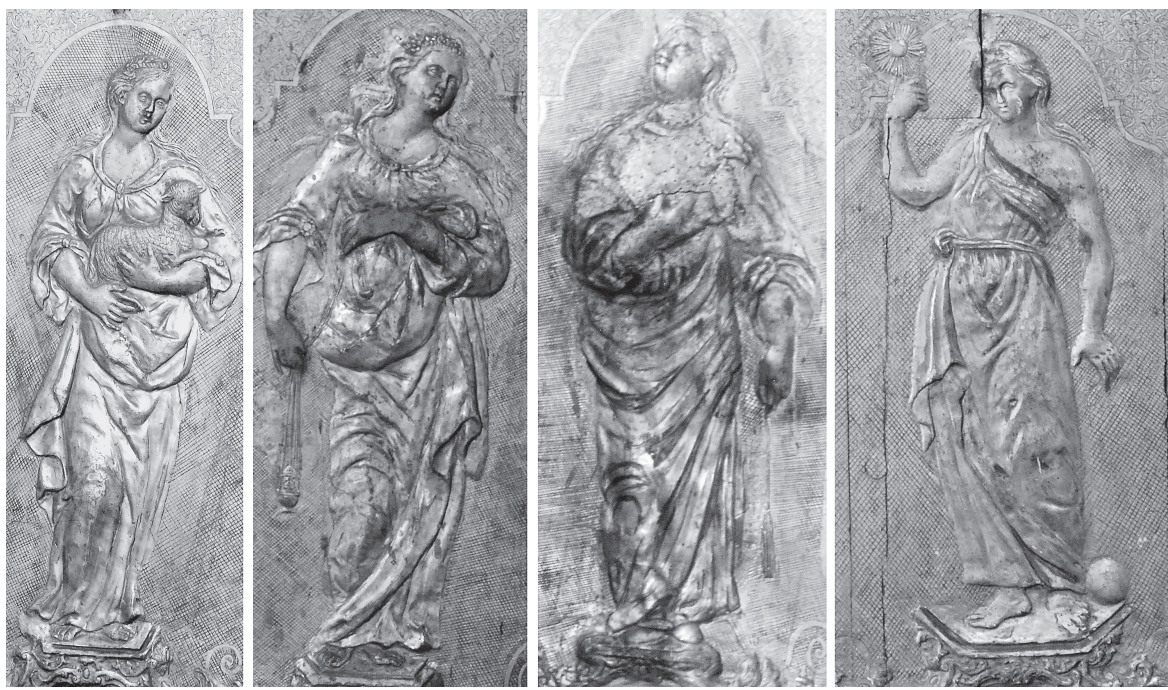

Fig. 11

Alegorías del basamento del retablo mayor: Humildad, Oración, Penitencia y Verdad.

mujer con traje blanco, lleva los ojos bajos, mientras sostiene en brazos un tierno Corderillo [...] El Cordero es verdadero símbolo y retrato del hombre humilde y manso...25. A continuación, una figura con un incensario podría ser la Oración, ya que el humeante incensario es símbolo apropiado de la Oración, afirmando el Profeta sobre esto en el CXL de los Salmos: Que mi oración se enderece, Señor, como incienso en tu presencia ${ }^{26}$. Al otro lado de la custodia tendríamos la Penitencia llevando un azote, dado que las disciplinas simbolizan la corrección de uno mismo ${ }^{27} \mathrm{y}$, por último, la Verdad, representada como una joven que

Ha de ir sujetando un Sol con una mano, simbolizándose con ello que la verdad es amiga de la luz, y aún que por símisma es una luz. clarísima, que nos muestra todo tal cual es [...] En cuanto al globo del Mundo que tiene bajo el pie, claramente significa que la verdad es superior a todas las cosas de este Mundo... ${ }^{28}$.

\footnotetext{
${ }^{25}$ Cesare Ripa, Iconología, tomo 1..., pág. 499.

${ }^{26}$ Cesare Ripa, Iconología, tomo 2, Madrid, Ediciones Akal, 1987, pág. 160.

${ }^{27}$ Cesare RiPA, Iconología, tomo 2..., pág. 192.

${ }^{28}$ Cesare Ripa, Iconología, tomo 2..., pág. 391. Ya García Iglesias propuso leer las tres últimas alegorías como la Oración -o bien, la Piedad-, la Penitencia y la Verdad, aunque, en su caso, interpretaba la primera como la Mansedumbre (José Manuel García IgLesias, "La capilla mayor...", págs. 196 y 197).
} 

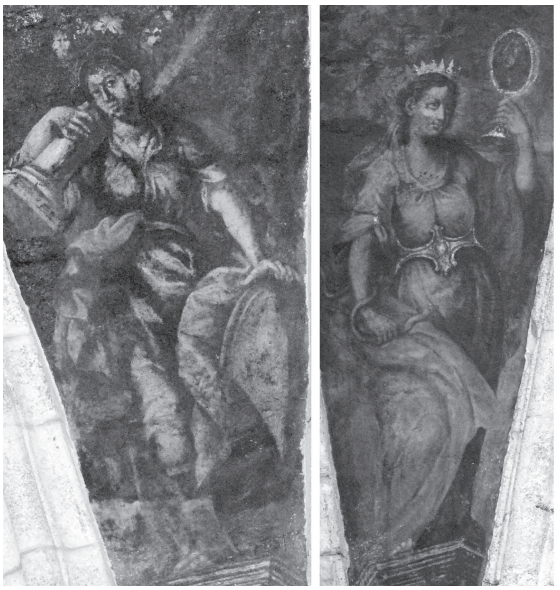
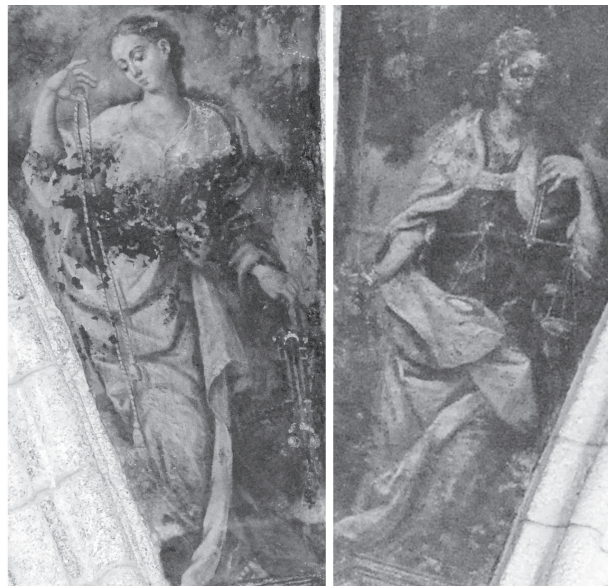

Fig. 12

Virtudes cardinales de la bóveda del presbiterio: Fortaleza, Prudencia, Templanza y Justicia

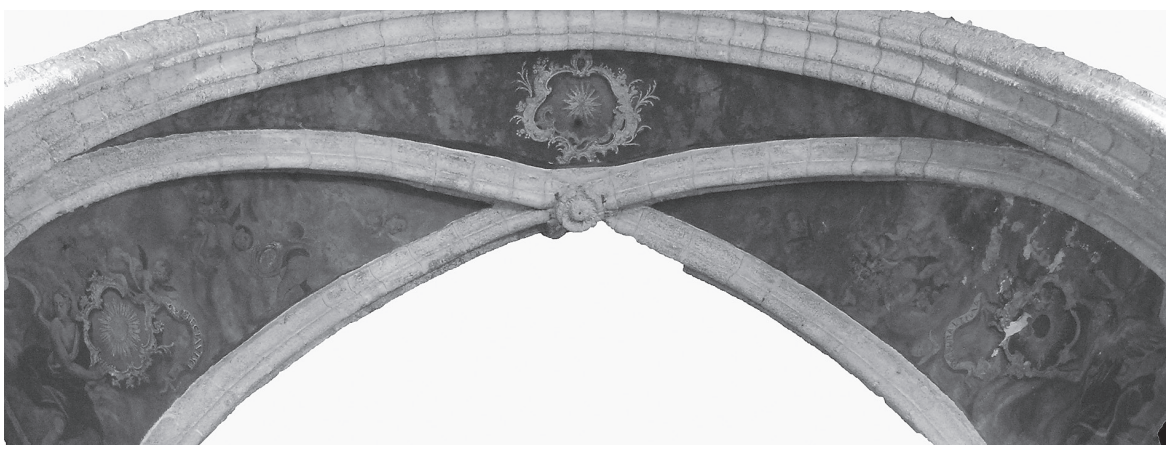

Fig. 13

Símbolos marianos de la bóveda del presbiterio:

Electa ut sol, Aurora consurgens y Pulchra ut luna.

\section{LOS TEMAS PINTADOS: LA CAPILLA MAYOR Y EL CRUCERO}

Subiendo ya a la bóveda, encontramos figuradas las cuatro virtudes cardinales (Fig. 12): la Fortaleza sosteniendo una columna porque de los elementos de un edificio éste es el más fuerte y el que sostiene a los otros ${ }^{29}$; la Templanza, con un freno en la mano izquierda a fin de representar la debida moderación de apetitos y pasiones $^{30}$; la Prudencia, contemplándose en un espejo y con una serpiente envuelta en su brazo, dado que:

\footnotetext{
${ }^{29}$ Cesare Ripa, Iconología, tomo 1..., pág. 437.

${ }^{30}$ Cesare Ripa, Iconología, tomo 2..., pág. 354.
} 

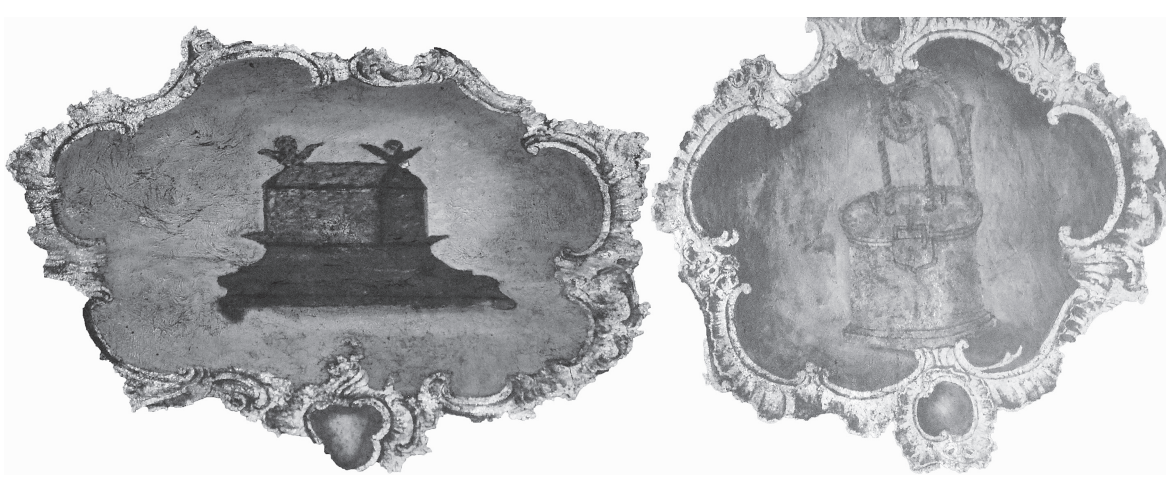

Fig. 14

Símbolos marianos de la bóveda del presbiterio: Arca de la Alianza y Pozo de Aguas Vivas.

el mirarse en el espejo sinifica en este caso la cognición de sí mismo, no siéndonos posible regular nuestras acciones sin tener el debido conocimiento de nuestros propios defectos. La sierpe [...] que por defender nuestra virtud y perfección, que vienen a equivaler a la cabeza, deberemos oponer a los golpes de fortuna la totalidad de nuestras fuerzas y recursos ${ }^{31}$.

Finalmente la Justicia, mirando

con los ojos hacia el mundo, considerándolo como cosa de la mayor bajeza. Sostendrá con la diestra una espada desnuda, sujetando con la siniestra una balanza [...] Las balanzas sinifican que la Divina justicia marca la pauta de todas las acciones, mostrándose con la espada las penas que les aguardan a quienes fueron delincuentes ${ }^{32}$.

Alternando con las virtudes, se disponen toda una serie de símbolos que la Iglesia le aplica a la Virgen María: la estrella, el sol, la luna (Fig. 13), el Arca de la Alianza, el pozo (Fig. 14), la torre, la puerta y el ciprés (Fig. 15). Se trata de imágenes poéticas extraídas del Antiguo Testamento que, si bien suelen asociarse a letanías como la lauretana o la bíblica, no son de su exclusividad, sino que, como vehículo para proclamar las prerrogativas de la Virgen, son habituales en los textos de los Padres de la Iglesia y en obras mucho posteriores, como el

\footnotetext{
${ }^{31}$ Cesare RiPA, Iconología, tomo 2..., pág. 233.

${ }^{32}$ Cesare RIPA, Iconología, tomo 2..., pág. 9.
} 

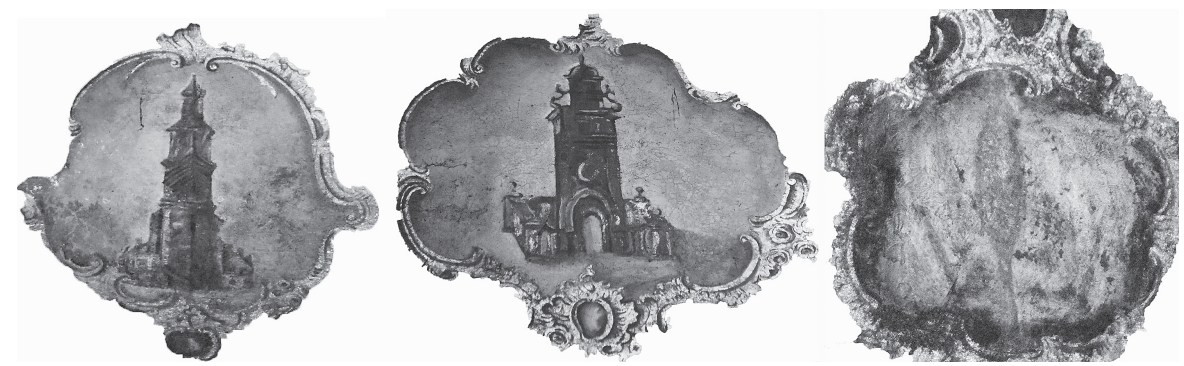

Fig. 15

Símbolos marianos de la bóveda del presbiterio: Torre de David/ Marfil, Puerta del Cielo y Ciprés.
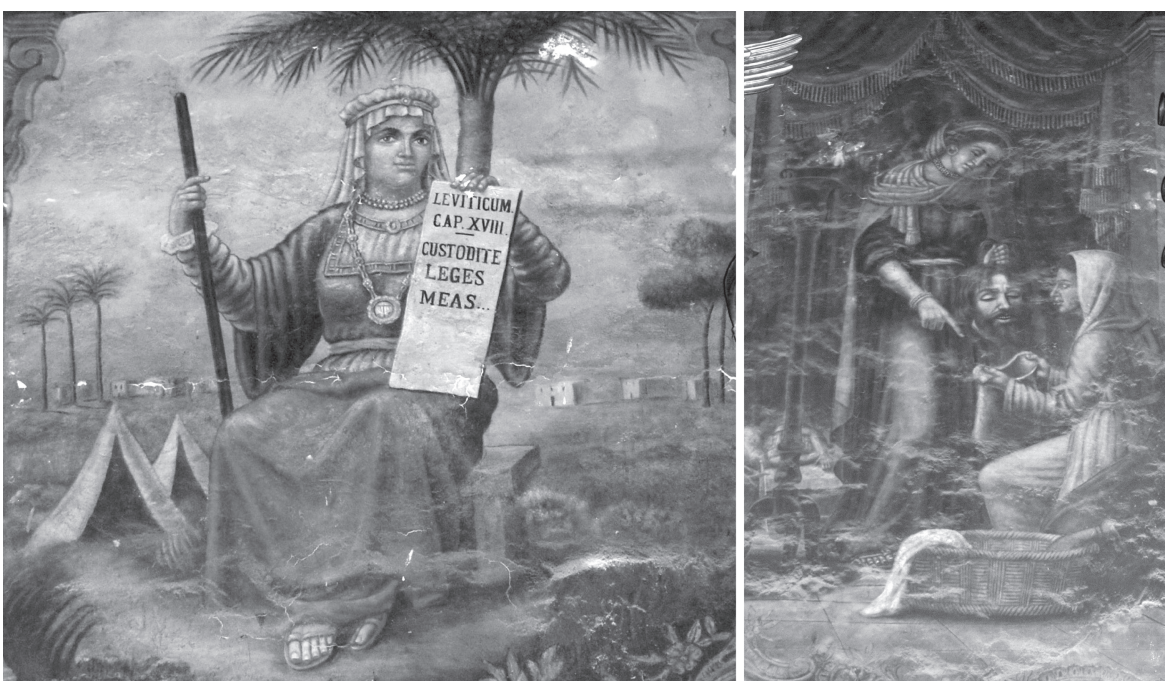

Fig. 16

Mujeres fuertes en el muro derecho del presbiterio: Débora y Judith.

Pancarpium Marianum de Jan David ${ }^{33}$. De hecho, esta obra propone un total de cincuenta títulos extraídos de las Sagradas Escrituras, de los cuales veintidós se trasladan a la Catedral de Lugo — en concreto, a la Capilla de Nuestra Señora de los Ojos Grandes- en la década de 1730, por tanto, pocos años antes de la intervención en la misma de José Francisco de Terán ${ }^{34}$.

\footnotetext{
33 Jan DAVID: Pancarpium marianum septemplici titulorum serie distinctum, Antuerpiae, ex officina Plantiniana, apud Balthasarem et Ioannem Moretos fratres, 1607.

${ }^{34}$ Carme López Calderón, Oración perpetua a la Madre de Dios: una aproximación iconográfica a la Capilla de Nuestra Señora de los Ojos Grandes, con apéndice de Inocencio Portabales, Tesis de Licenciatura, Santiago de Compostela, 2011, págs. 61-189.
} 

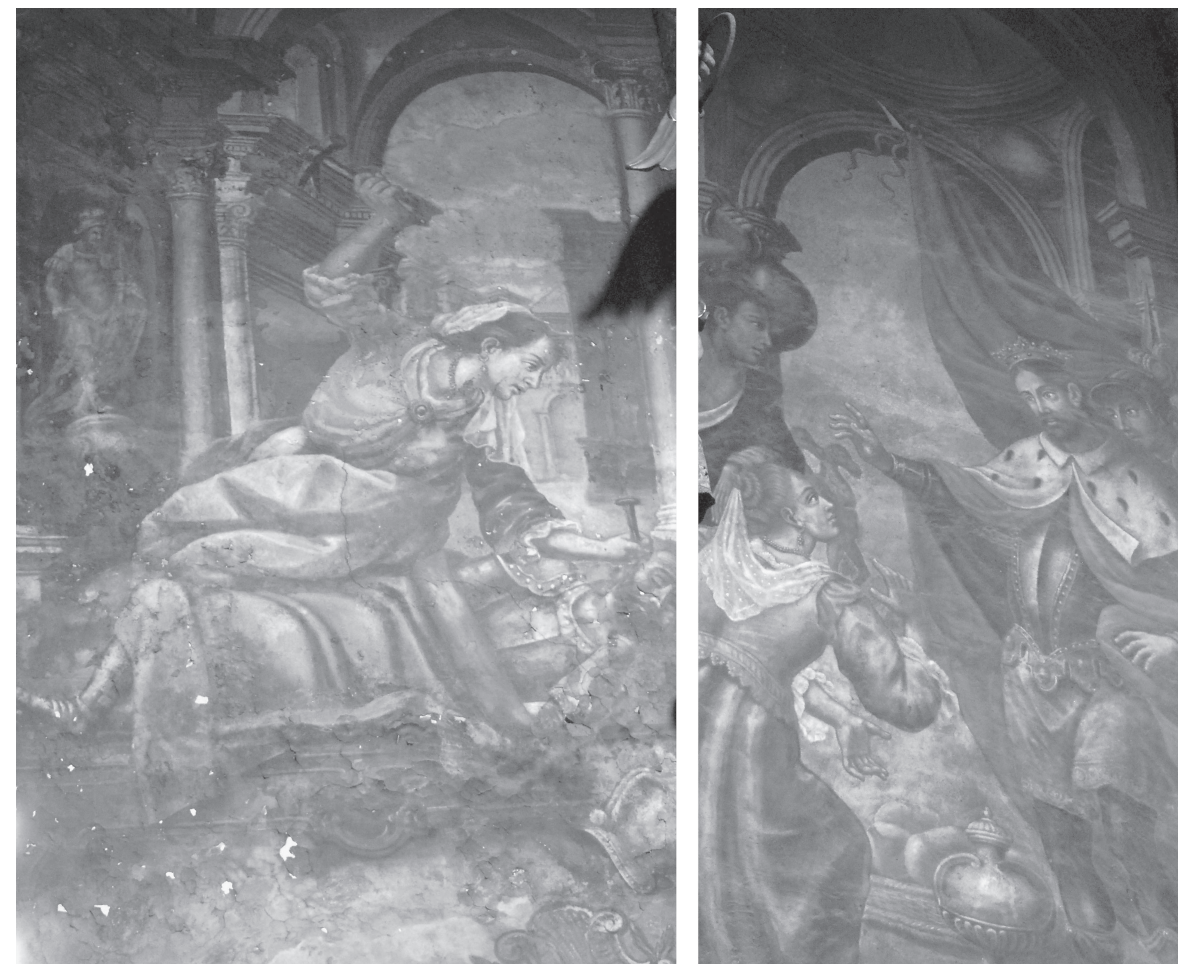

Fig. 17

Mujeres fuertes en el muro izquierdo del presbiterio: Jael y Abigail.

Cuatro nuevas prefiguraciones marianas reaparecen en las paredes del presbiterio, pero, en este caso, antropomórficas: se trata de las llamadas Mujeres Fuertes. En concreto, a un lado se nos muestra a Débora, profetisa y juez de Israel, bajo la palmera desde donde impartía justicia ${ }^{35} \mathrm{y}$ a Judith, quien, tras haber decapitado a Holofernes, introduce su cabeza en la bolsa que le ofrece una criada ${ }^{36}$ (Fig. 16); al otro, a Jael, en el momento en que mata a Sísara clavándole en la sien un clavo de los de fijar la tienda ${ }^{37} \mathrm{y}$, según los autores, a Abigail ante David, o a Ester ante Asuero $^{38}$ (Fig. 17). Personalmente nos decantamos por la primera de las opciones, dado que los panes y el cántaro con vino remiten a las ofrendas

\footnotetext{
35 Jueces, 4:4-5.

36 Judith, 13:11.

37 Jueces, 4:17-18.

${ }^{38}$ Mientras San Cristóbal Sebastián se decanta por Abigail ante el Rey David (Sebastián SANTOS SAN CRistóbal, La catedral..., pág. 40), otros autores refieren ambas posibilidades (José Manuel García Iglesias, "La capilla mayor..., págs. 199-200; Enrique Fernández Castiñeiras y Juan Manuel Monterroso Montero, "Ecclesia, Domus...”, pág. 190).
} 
con las que Abigail logra aplacar la cólera de David suscitada por la avaricia de su esposo ${ }^{39} \mathrm{y}$, si bien es cierto que el marco palaciego que alberga la escena no coincide con el descrito en los textos sagrados, lo mismo sucede con el de Jael, con el que, precisamente, esta representación hace pendant.

Ya por último, en la bóveda del crucero se recogen cuatro escenas de otros tantos reyes de la casa de David (Fig. 3): El Juicio de Salomón ${ }^{40}$; la victoria de Josafat sobre los amonitas y los mohabitas ${ }^{41}$; Ezequías destruyendo los ídolos paganos: las piedras paradas, los postes sagrados y la serpiente de bronce ${ }^{42}$; y Josías profanando los altares al inmolar en ellos a los sacerdotes de los Altos Lugares, cumpliéndose así el vaticinio del profeta de Betel $^{43}$.

\section{El PORQUÉ DE LOS TEMAS: HACIA UNA LECTURA ICONOLÓGICA DEL CONJUNTO}

Tal y como señala E. Gombrich:

el iconólogo procede a tender un puente entre ambas orillas [la de los textos y la imagen] para salvar el foso que separa la imagen del tema. La interpretación se convierte en reconstrucción de una prueba perdida. Esta prueba, además, no sólo debe ayudar al iconólogo a determinar cuál es la historia ilustrada, sino que su objetivo es averiguar el significado de esa historia en ese contexto concreto [...] Pues toda investigación iconológica depende de nuestra idea previa respecto a lo que estamos buscando, o, en otras palabras, de nuestra opinión sobre lo que es o no plausible en el seno de una época o un ambiente dados ${ }^{44}$.

Consecuentemente, la reconstrucción de nuestra "prueba perdida" —el programa que explique los temas desarrollados en la capilla mayor y la bóveda del crucero de la catedral de Mondoñedo- nos exige recrear el contexto, tanto temporal como espacial, que la hace factible.

La catedral de Mondoñedo está dedicada a Santa María, de ahí que, como resulta habitual en los templos bajo esta advocación, la imagen que preside el retablo es una Asunción. Ello es lógico, dado que la Asunción de la Virgen cons-

\footnotetext{
${ }^{39}$ Libro I de Samuel, 25:18 y ss.

401 Reyes 3:25.

412 Crónicas 20:22-24.

422 Reyes 18:4.

431 Reyes, 13:2 y 2 Reyes, 23:20.

${ }^{44}$ Ernest Gombrich: Imágenes simbólicas..., pág. 18.
} 
tituye una de las demostraciones más elocuentes de su triunfo, en la medida en que confirma tres de sus prerrogativas, que, con el tiempo, se convirtieron en dogma: la Maternidad Divina, la Virginidad Perfecta y Perpetua y la Inmaculada Concepción ${ }^{45}$. Al respecto, y según enseña el Magisterio de la Iglesia, el pecado conduce a la corrupción y, por tanto, a la muerte; si en María no existe pecado original, porque su concepción es inmaculada, ni pecado carnal, porque concibe virginalmente a Cristo, se concluye que su alma y su cuerpo son ajenos al pecado y, por tanto, incorruptibles, de ahí que pueda ser Asunta en cuerpo y alma a los cielos. Al mismo tiempo, ya desde la patrística los autores reivindican que esta prerrogativa es necesaria en la Madre de Dios, pues no es admisible que tú, el receptáculo de Dios, quedaras reducida al polvo, tal como los cadáveres se descomponen ${ }^{46}$.

Efectivamente, ya desde los inicios del cristianismo, los Padres de la Iglesia primero y numerosos teólogos después defienden que María goza de unas prerrogativas que la hacen superior a las demás criaturas y cuya razón de ser estriba en su elección como Madre de Dios ${ }^{47}$. A lo largo de los siglos, surgen diversas corrientes consideradas heréticas que cuestionan algunas de estas prebendas, lo que provoca que desde la ortodoxia se enfatice su defensa. En este sentido, en el siglo XVI y dentro de la reforma de la Iglesia Romana propuesta por movimientos como el luteranismo y el calvinismo, buena parte de los privilegios de la Virgen son objeto de crítica; como contrapunto, dentro de la Iglesia Contrarreformista cobra nuevos bríos el sentimiento de fervor mariano, el cual, enlazando con el ya vivido a finales del Medievo, explica, entre otras cuestiones, el auge de devociones como la del Rosario, la exaltación de la Virgen como vencedora de las herejías y la recuperación y ampliación de aquellos títulos que la tradición le venía aplicando desde tiempos antiguos ${ }^{48}$. Igualmente, en estos momentos adquiere especial relevancia la proclamación de María como la más excelsa Mediadora y Corredentora, elogio que enlaza con la afirmación tridentina del papel

\footnotetext{
45 En este sentido, tal y como señala G. Pons, ya en la Homilía sobre la Asunción de la Santa Madre de Dios que escribe Teotecno de Livia se pone de manifiesto que la glorificación de María asunta en cuerpo y alma al cielo, se fundamenta en la dignidad excelsa de la Madre de Dios, en su virginidad perpetua y en su santidad insigne (Guillermo Pons, Textos marianos de los primeros siglos. Antología patrística, Madrid, Ciudad Nueva, 1994, págs. 219-220).

46 San Germán de Constantinopla, cit. por Guillermo Pons, Textos marianos..., pág. 255.

${ }^{47}$ Callen todas la interpretaciones, pues una sola encierra todas las glorias de la Virgen. Qué no será la que es Madre de Dios? (Francisco García, Cinco sermones del Santissimo y Dulcissimo nombre de María, Madrid, por Juan García Infançon, 1681, epílogo, s.p.).

48 Santiago Sebastián, Contrarreforma y Barroco. Lecturas iconográficas e iconológicas, Madrid, Alianza Editorial, 1985, págs. 195-201.
} 
intercesor de los santos ${ }^{49}$ y que, una vez más, ratifica su superioridad sobre toda criatura; no en vano, es la persona más próxima a Dios.

Asimismo, dentro de este contexto general de apología mariana y pocos años antes de que Francisco José Terán contrate el retablo, el mundo hispánico recibe un reconocimiento fundamental en recompensa de su tradicional defensa del nacimiento sin mancha de la Madre de Dios: en 1760, Clemente XIII proclama oficialmente a la Inmaculada Concepción Patrona de España y de todos sus do$\operatorname{minios}^{50}$.

En realidad, ya en 1634 el cabildo mindoniense, continuando la estela de otras sedes, universidades y ciudades españolas, realiza un primer voto-juramento inmaculista seguido por otros muchos en la misma catedral, en los cuales se constata una evolución terminológica que evidencia el desarrollo progresivo del misterio hasta ser proclamado dogma en $1854^{51}$. Teniendo en cuenta que la fe popular desempeña un papel crucial en dicha definición ${ }^{52}$, no resulta extraño que en 1761, al conocerse en Mondoñedo el breve que otorga el patronazgo de la Inmaculada, se comunique a los vecinos la víspera de la Natividad de María por medio de luminarias públicas y generales y fijación de carteles, y que asimismo el Concejo encargue a José Jacinto Vaamonde y a Pedro Sordo iluminar aquella noche el balcón de estas casas [del Ayuntamiento] con cera y mandar se encarguen asta la cantidad de trescientos reales de fuegos, que se dispararán desde ellas ${ }^{53}$.

Consecuentemente, este ambiente generalizado de devoción a la Virgen explica que, en un espacio asimismo consagrado a ella, se ejecute un programa destinado a cantar sus excelencias ${ }^{54}$. Con esto, el cabildo mindoniense se ins-

\footnotetext{
${ }^{49}$ Los movimientos reformadores, al defender que los hombres se salvan exclusivamente por su fe, y no por sus obras, niegan la labor intercesora de los santos, lo que lleva al Concilio de Trento a afirmar en su sesión XXV que los santos que reinan juntamente con Cristo, ruegan a Dios por los hombres; que es bueno y útil invocarlos humildemente, y recurrir a sus oraciones, intercesión, y auxilio para alcanzar de Dios los beneficios por Jesucristo su hijo, nuestro Señor, que es sólo nuestro Redentor y Salvador...

${ }^{50}$ Giorgio Sernani, Los dogmas de María. Las piedras más preciosas de su corona, Buenos Aires, Publicación de la Orden de María Reina, 2002, págs. 74-76.

${ }^{51}$ Enrique CAL PARDO, "El voto inmaculista en la catedral de Mondoñedo", Estudios Mindonienses, 8 (1992), págs. 371-417.

${ }^{52}$ Stefano de Fiores y Salvarore Meo (dir.), Nuevo diccionario de mariología, Madrid, San Pablo, 1988, pág. 912.

${ }^{53}$ Enrique CaL PARdo, "El voto inmaculista..., pág. 384.

${ }^{54}$ Carecemos de cualquier noticia documental que nos permita conocer quién fue el autor intelectual de este programa. No obstante, teniendo en cuenta que el conjunto se ejecuta en pleno pontificado de Don José Francisco Losada y Quiroga (1762-1779), de quien ya Cal Pardo señaló "no que él haya sufragado, de su peculio particular, estas obras; pero no se puede dudar de que él las impulsó y alentó" (Enrique CAL PARDo, Episcopologio mindoniense. Santiago de Compostela,
} 
cribe en una tendencia generalizada durante los siglos XVII y, especialmente, XVIII en todos los países del orbe católico, en los cuales proliferan conjuntos que, ya sea a través de escenas figurativas o de repertorios emblemáticos, exaltan las prerrogativas que la Iglesia de Roma atribuye a la Deipara ${ }^{55}$.

Consejo Superior de Investigaciones Científicas, Instituto de Estudios Gallegos Padre Sarmiento, 2003 (Anejos de Cuadernos de Estudios Gallegos, 28), pág. 797), es probable que este obispo participase, de un modo más o menos directo, en su elaboración. Al respecto, en la biblioteca que poseía antes de iniciar su labor pastoral en Modoñedo - de la que tenemos constancia gracias al inventario de bienes y declaración de patrimonio que realiza el 17 de septiembre de 1761, ante el secretario José Faustino Medina, y que actualmente puede consultarse en $<$ http://galiciana.bibliotecadegali-

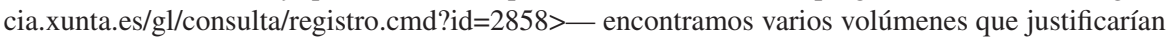
los necesarios conocimientos mariológicos, tal es el caso de los tres tomos de la Venerable Madre María de Agreda, Mística ciudad de Dios, los tres tomos de Coutiño, Marial, Santoral y Quaresma, los dos tomos de Barcia, Despertador Christiano, o la Vida de Nuestra Señora de Mendoza.

${ }^{55}$ Simplemente por citar algunos ejemplos, podemos aludir a la puerta central de la fachada occidental de la catedral de Pisa, cuyo programa, ejecutado entre 1596-1603, combina escenas figurativas de la vida de María con emblemas que redundan en esos mismos episodios (Hans Martin Von Erffa, "Das Programm der Westportale des Pisaner Domes", Mitteilungen des Kunsthistorischen Institutes in Florenz, 12 (1965), págs. 55-106), al Santuario de Hergiswald en Lucerna, en donde Kaspar Meglinger decora en 1654 los más de trescientos casetones que componen la bóveda con emblemas marianos (Dieter BITTERLI, Der Bilderhimmel von Hergiswald: der barocke Emblemzyklus der Wallfahrtskirche Unserer Lieben Frau in Hergiswald bei Luzern, seine Quellen, sein mariologisches Programm und seine Bedeutung, Basel, Wiese, 1999) y al Santuario Basilica de Santa Maria delle Grazie en Brescia, en donde algunas de las pinturas que decoran la bóveda están tomadas del Pancarpium Marianum de Jan David (Angelo LoDA, "Il sangue del Redentore. Testimonianze figurative eucarístico-sacramentali nella diocesi di Brescia", Brixia Sacra. Memorie Storiche della Diocesi di Brescia, 1-2 [1999], págs. 52-70), obra que, como antes comentamos, igualmente se mimetizó en la década de 1730 en Capilla de Nuestra Señora de los Ojos Grandes de Lugo. También por estas fechas, la bóveda del Santuario de Nuestra Señora de las Ermitas de Ourense se enriquece con algunos de los Jeroglíficos inmaculistas de Fray Nicolás de la Iglesia (Miguel Ángel González García y José Hervella Vázquez, "Emblemática y Mariología: el santuario de Nuestra Señora de las Ermitas y los Hieroglíficos Sagrados de Fray Nicolás de la Iglesia", en Sagrario López Poza (ed.), Literatura emblemática hispánica. Actas del I Simposio Internacional, Coruña, Universidade da Coruña, Servicio de Publicaciones, 1996, págs. 501-514), libro, indisolublemente vinculado a la Capilla de la Inmaculada en la Cartuja de Miraflores (Patricia ANDrÉs GonzÁlez, "Emblemas marianos de la Capilla de la Virgen en la Cartuja de Burgos. El modelo pintado y su repercusión iconográfica", Boletín del Seminario de Estudios de Arte y Arqueología: BSAA, 69-70 (2003-2004), págs. 383-409 y Reyes Escalera Pérez, "Emblemática mariana. Flores de Miraflores de Fray Nicolás de la Iglesia”, Imago. Revista de Emblemática y Cultura Visual, 1 (2009), págs. 45-63). Coetánea ya a Mondoñedo es la Capilla viseense de Nuestra Señora de la Esperanza: un auténtico monumento de exaltación mariana, en donde todos los elementos - desde la decoración pictórica a la azulejar, pasando por el órgano y la talla— se ponen al servicio de la alabanza de la Virgen (Carme López CaLderón, "La emblemática como instrumento devocional: la Capilla de Nossa Senhora da Esperança en Abrunhosa (Viseu, Portugal)", A. Martínez Pereira, I. Osuna y V. Infantes (eds.): Palabras, símbolos, emblemas. Las estructuras gráficas de la representación, Madrid, Turpín Editores, Sociedad Española de Emblemática, 2013, págs. 299-311. 
De esta manera, el discurso mariano esgrimido en el mundo contrarreformista presenta un carácter unitario, coherente y universal, de ahí que, en base al mismo, podamos reconstruir e interpretar el programa mindoniense.

Comencemos por las Sibilas. Como antes indicábamos, sus profecías se han puesto en relación con diversos episodios de la vida de Cristo y María, pero lo cierto es que habitualmente, cuando se analiza su presencia en conjuntos sacros, se suele hacer hincapié en su filiación cristológica. En este caso, no obstante, creemos que debemos enfatizar sus connotaciones mariológicas, a las cuales también alude Baltasar Porreño en la obra que dedica a estas profetisas paganas.

Así, respecto a la Sibila Pérsica (Fig. 7), la profecía recogida en la parte inferior de la xilografía comienza indicando El linaje amado de Dios nacerá de una Virgen Madre y será causa de salvación para el pueblo caído, añadiendo luego el autor que también

se le atribuye comúnmente la siguiente profecía: La gran bestia será atropellada, el Señor nacerá en la tierra de las entrañas de una virgen [...] Es conforme al lenguaje del Espíritu Santo en el Génesis, donde amenaçando Dios al Demonio, bestia y serpiente maligna, le dixo: Ella aplastará tu cabeza [...] También ella se entiende por la Virgen nuestra Señora, que fue la que quebrantó al Demonio la cabeça, naciendo Christo de sus entrañas, y siendo madre y virgen, parida y doncella [...] Dezir que el Señor avía de nacer en la tierra de las entrañas de una donzella, es conforme a lo que escrive Esaías: La Virgen concebirá y parirá un hijo, y le pondrá por nombre Emanuel ${ }^{56}$.

En lo relativo a la Délfica (Fig. 8), la profecía inicial alude a "la edad en que Dios nacerá de un alma virgen", señalando Porreño a continuación que

Entre sus versos, traducidos del Griego, se hallan los siguientes [...] Este divino Señor y Dios, concebido del virginal vientre, procederá sin junta de varón, la qual divina obra vence a todas las de naturaleza [...] Así el Hijo de Dios tiene Padre Eterno en el cielo, y madre temporal en la tierra, cuya divina Encarnación fue sin alteración, ni mutabilidad del Eterno Padre, y sin corrupción de la temporal madre ${ }^{57}$.

\footnotetext{
${ }^{56}$ Baltasar Porreño, Oráculos..., fols. 7v.y 8v.-9r.

${ }^{57}$ Baltasar Porreño, Oráculos..., fols. 18r. y 20r.
} 
En cuanto a la Sibila Cumana (Fig. 9), la primera profecía refiere que: Será hecho Dios y hombre, ofrecerá los triunfos de la vida y la muerte: Hijo de Virgen y Madre, a lo que el autor añade

\begin{abstract}
Hállanse desta Sibilla unos versos en alabança de la Virgen nuestra Señora, que dizen así: El que es humilde en todas las cosas amará, y escogerá por madre una donzella, y esta hará ventaja en hermosura a todas las del mundo [...] A la hermosura de su madre corresponden aquellas palabras de la Esposa: Hermosa como la Luna, y escogida como el Sol ${ }^{58}$.
\end{abstract}

Finalmente la Frigia (Fig. 10) comienza su profecía señalando: El linaje del cielo desciende devoto a las entrañas de la intacta Virgen Madre ${ }^{59}$.

En resumidas cuentas: en los oráculos de estas cuatro sibilas encontramos referencias a lo que habitualmente se denomina la Maternidad Virginal o Virginidad fecunda de María, nombres que resumen las dos prerrogativas que primero fueron proclamadas dogma - la Maternidad Divina (Concilio de Éfeso, 431) y la Virginidad (Concilio de Letrán, 649) — y que precisamente son, junto con su Inmaculada Concepción, las que, como antes explicábamos, permiten su Asunción en cuerpo y alma a los cielos.

En la parte superior del retablo y flanqueando la Asunción se disponen el esposo y los padres de María (Fig. 4). La presencia de estas figuras no es extraña en un retablo del siglo XVIII, dado que, a estas alturas y pese a haber sido tardía, la devoción a san José y a los abuelos se había generalizado, favorecida en parte por la labor mediadora que Trento otorga a los santos. Así, mientras san José se convierte en el protector de la buena muerte ${ }^{60}$, san Joaquín y santa Ana actúan como intercesores ante la más excelsa mediadora, que es la Virgen. En este sentido, el Padre Ribadeneyra aconseja que:

Seamos devotos destos gloriosos Padres de la Madre de Dios, pues son tan grandes sus méritos, y eficaces sus oraciones, porque assí

\footnotetext{
${ }^{58}$ Baltasar Porreño, Oráculos..., fols. 23v. y 27v.-28r.

${ }^{59}$ Baltasar Porreño, Oráculos..., fol. 46r.

${ }^{60}$ Pero entre todos aquellos deben escoger y tomar con más empeño por su Abogado a San Josef que desean morir con aquella muerte apacible de los justos y preciosa en la presencia del Señor [...] Josef es uno de los Potentados más poderosos en el Cielo, en donde reside, como Padre del Rei, y como Esposo de la Reina y Señora del Universo: títulos que lo hacen tan formidable a los espíritus infernales, que no se atreven a acercarse a la cama del moribundo que ha implorado su protección (José Ignacio VAllejo, Vida del Señor San Josef dignísimo esposo de la Virgen y padre putativo de Jesús, Cesena, Imprenta de Gregorio Biasini, 1779, págs. 246-247).
} 
como la Virgen puede mucho con Dios, por ser Madre suya, assí ellos pueden mucho con la Madre de Dios, por ser Hija suya, la qual se huelga que honremos a sus Santíssimos Padres ${ }^{61}$.

En cualquier caso, lo que sí resulta curioso es la participación que estos personajes semejan tener en el misterio que alberga la calle central, dado que, al volverse y mirar hacia la Virgen, parece que también ellos salen a recibirla (Fig. 1). Decimos que es curioso porque ni en los Evangelios Apócrifos ni en la Leyenda Dorada se menciona a san José, san Joaquín o santa Ana como parte integrante del cortejo celestial que aclama a María en su subida a los cielos. Si acudimos entonces al principio corrector del análisis iconográfico propuesto por Panofsky, la historia de los tipos ${ }^{62}$, encontramos al menos un precedente cercano que sí los representa de este modo: el fresco de Lucas Jordán dedicado al Tránsito y Asunción de la Virgen y ubicado en la bóveda del crucero inmediata a la capilla mayor en la Iglesia de El Escorial.

Estas pinturas recibieron una destacada difusión en la época por medio de obras como Descripción del Real Monasterio de san Lorenzo de El Escorial, única maravilla del mundo, de Francisco de los Santos ${ }^{63}$, El museo pictórico y escala óptica de Antonio Palomino ${ }^{64}$ y Descripción del Real Monasterio de San Lorenzo del Escorial, su magnífico templo, panteón y palacio, de Andrés Ximénez ${ }^{65}$. Respecto al fresco en cuestión, el primero de los autores señala Arriva, entre doradas nubes, se ven descender del Cielo los Padres de María Santíssima y su Esposo san Ioseph; piadosa y devota introducción ${ }^{66}$, mientras que Palomino

\footnotetext{
${ }^{61}$ Pedro de Ribadeneyra, Flos Sanctorum, de las vidas de los santos, tomo primero, Barcelona, Imprenta de Juan Piferrer, 1734, pág. 441.

62 Erwin Panofsky, Estudios sobre iconología, Madrid, Alianza, 1972, págs. 21-22.

${ }^{63}$ Francisco de los Santos, Descripción del Real Monasterio de San Lorenzo de el Escorial, única maravilla del mundo, Madrid, Imprenta de Juan García Infançon, 1698.

${ }^{64}$ Antonio Palomino, El museo pictórico y escala óptica, Tomo segundo, práctica de la pintura, Madrid, Viuda de Juan García Infançon, 1724. Justamente, Fernández Castiñeiras puso en relación el estilo de José Francisco Terán con la obra de Palomino, indicando: "Influencias, rasgos, toques, armonías, y notas de los grandes maestros del Barroco como Rubens y Tiépolo las encontraremos más o menos asimiladas, disminuidas o estimuladas. No obstante, la comprensión de su pintura entendemos que debe hacerse a partir de la obra de Antonio Palomino: "El museo pictórico y escala óptica", que, publicada entre 1715 y 1724, se convertiría en un manual para un buen número de pintores” (Enrique Fernández CastiñeIras, “El lenguaje..., pág. 48).

65 Andrés Ximenez, Descripción del Real Monasterio de San Lorenzo del Escorial, su magnífico templo, panteón y palacio, Madrid, Imprenta de Antonio Marín, 1764. En realidad, la descripción que realiza de los frescos de la iglesia es una paráfrasis — cuando no, una copia directa— de la que, años atrás, había publicado Francisco de los Santos, de ahí que, en lo sucesivo, optemos por omitirla.

${ }^{66}$ Francisco de los Santos, Descripción..., fol. 31v.
} 
indica sobre el florido Lecho Virginal [...] en lo alto, con piadosa introducción, se ven descender los Gloriosos Padres de esta Gran Señora, y su Felicísimo Esposo, a recibir su Alma Sacratísima ${ }^{67}$.

Pero las similitudes con la intervención de Jordán van más allá, puesto que tres de las pechinas que sostienen la bóveda escurialense dan cabida a tres de los reyes bíblicos que ocupan el crucero de la Catedral de Mondoñedo: Josafat, Ezequías y Josías. Francisco de los Santos ${ }^{68}$ y Palomino ${ }^{69}$ explican la presencia de Josafat porque a su Valle es llevado desde Jerusalén, en hombros de los apóstoles, el Cuerpo de María. En nuestro caso, el rey se figura venciendo a Moabitas y Amonitas tras haberse encomendado al Señor, episodio que en el siglo XVII se utiliza para referir el poder mediador de la Virgen:

quando estando el Emperador Estratónico sitiado dentro della [Constantinopla], y con notable peligro assí de su persona, como de la ciudad [...] se fue a los pies de cierta Imagen de la esclarecida Reyna, y puesto de rodillas la ofreció una humilde oración, qual en semejante peligro avía presentado el Rey Iosaphat ante el Señor, estando cercado por todo el poder de los Moabitas y Amonitas, la qual remató con las palabras siguientes: En nosotros Señor, no ay tanta fortaleza ni poder, que podamos resistir a esta tan grande multitud que ha venido sobre nosotros; mas como quiera que ignoremos que devamos hazer, esta sola guarida y remedio tenemos, levantar nuestros ojos a ti. Esto se cumplió también a Estratónico... ${ }^{70}$.

Por lo que respecta a Josías y Ezequías, Palomino comenta que sus nombres (según el Doctor Máximo) suenan lo mismo, que Fuego y Fortaleza del Señor: prerrogativas bien acreditadas en esta Gran Reyna ${ }^{71}$. Francisco de los Santos desarrolla un poco más esta comparación explicando que Josías significa Fuego por esso tiene en la mano unas llamas, y en la otra el Volumen de la Ley; en muestra del ardiente zelo de su observancia en que tanto floreció la que en todo se rindió a la Ley ${ }^{72}$. Es decir: en el Escorial, a través de este patriarca se refiere el acatamiento de María de la Antigua Ley, tal y como demostró con su

\footnotetext{
${ }^{67}$ Antonio Palomino, El museo pictórico..., pág. 469.

${ }^{68}$ Francisco de los SAntos, Descripción..., fols. 31v.-32r.

69 Antonio Palomino, El museo pictórico..., pág. 469.

${ }^{70}$ Pedro Hernández, Tratado de las festividades de la Santíssima Virgen María, Madre de Dios y Señora Nuestra, Madrid, Luis Sánchez, 1618, pág. 40.

71 Antonio Palomino, El museo pictórico..., pág. 469.

72 Francisco de los Santos, Descripción..., fol. 32r.
} 


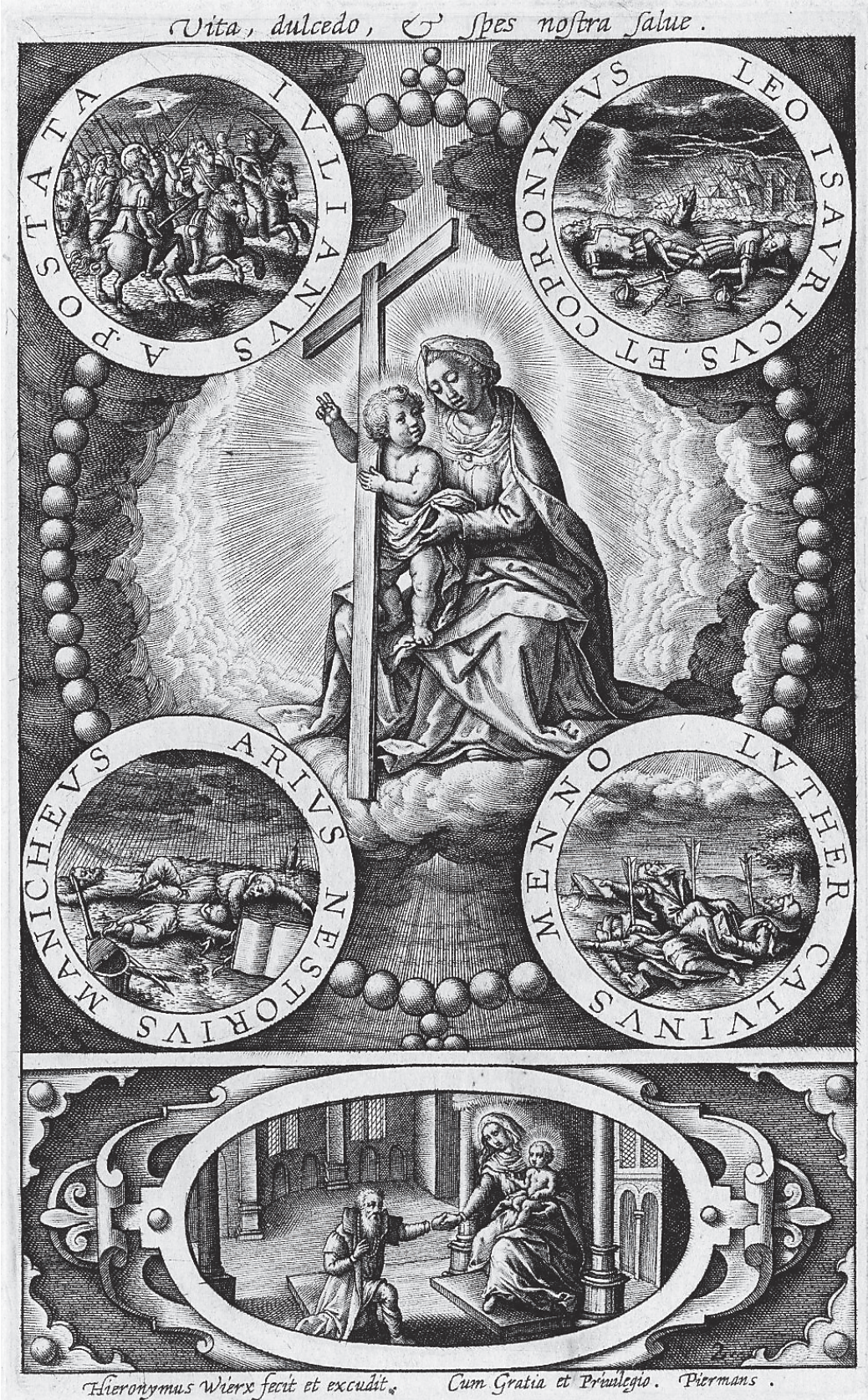

Fig. 18

Hieronymus Wierix, Salve Regina, ca. 1619, estampa 2 (@ Trustees of the British Museum). 
Purificación y con la Presentación de Jesús en el Templo. En nuestro caso, Josías se representa igualmente haciendo gala de ese ardiente celo, dado que profana los altares y destruye los ídolos tras haber leído el libro de la ley; ahora bien, precisamente esta lucha contra lo que se aparta de la ortodoxia también puede evocarnos el título de María como vencedora de la herejía; título que, como antes indicamos, recupera la Contrarreforma e ilustra, por ejemplo, Hieronymus Wierix al mostrar su triunfo sobre Juliano Apóstata, Constantino Coprónimo, León el Armenio, Ario, Nestorio, Maniqueo, Lutero, Calvino y Menno Simons (Fig. 18) ${ }^{73}$.

Ezequías, por su parte, significa Fortaleza del Señor, de ahí que en el Escorial se muestre: mirando al Cielo, recostado a una Coluna. Fue el que con fortaleza hizo se atendiesse mucho a la decencia del Templo de Jerusalén, sombra de María, Templo de Dios ${ }^{74}$. En Mondoñedo, al igual que sucedía con Josías, Ezequías figura combatiendo la idolatría en un episodio que, además, ya en el siglo XIX, sirve para exaltar la fe de la Virgen María y, nuevamente, su victoria sobre los herejes:

Ezequías, rey de Judá, tenía su esperanza puesta en el Señor: siendo su guía la esperanza, hizo desaparecer los Altos Lugares, derribó las estatuas, reemplazó los bosques sagrados [...] María, firmemente asegurada en la esperanza, ampliamente supera al rey Ezequías en tener puesta su esperanza en Dios [...]: más fuertemente que Ezequías hizo desaparecer los altos lugares, derribó las estatuas, reemplazó los bosques sagrados, abatió los dioses ajenos [...] destruyó por sí sola todas las herejías del mundo entero... ${ }^{75}$.

En relación con ello, los autores insistirán continuamente en que María aventaja a todas las criaturas en virtud, lo que incluye las Virtudes teologales y cardinales que, como veíamos, decoran la capilla (figs. 6 y 12). Para comprobarlo, podemos acudir a libros como la Historia de la Virgen María (1651) en cuyo índice se anuncian los capítulos: De la hermosura interior de la Virgen en la perfección de las virtudes Theologales, y en particular de la fe; De quan ilustrada estuvo la Virgen de la virtud de la esperança; De su caridad ferventíssima y de las muchas causas que la esforçaban; De quan perfectas e ilustradas estuvieron en la Virgen las virtudes Cardinales, Prudencia y Iusticia; De la eminencia, con

\footnotetext{
${ }_{73}$ Hieronymus WiErix, Salve Regina, ca. 1619, estampa 2.

${ }^{74}$ Francisco de los Santos, Descripción del Real Monasterio..., op. cit., fol. 32r.

75 Joseph Jean de Smet: Mensis marianus, Gandae, typis Fratrum J. et H.Vander Schelden, 1858, pág. 37.
} 
que estuvo en la Virgen la virtud de la fortaleça; De quan ilustrada estuvo en la Virgen la virtud de la templança en todas sus especies ${ }^{76}$.

En ocasiones, estas virtudes se expresan a través de los símbolos veterotestamentarios que prefiguran a María. En el Pancarpium Marianum, por ejemplo, se compara a María con el Altar de Incienso, identificando el oro que lo recubre con las virtudes Teologales — “¿Quién deseó para esta los anillos de oro, que apreció su fe, al encadenarse a Dios, y su caridad, al ofrecerse para la salud de todo el mundo?"77 - y las cuatro puntas que asoman en la parte superior del altar, con las cardinales — “ ¿Y acaso le faltaron a aquel altar nuestro, la Virgen divina, las cuatro puntas de las virtudes cardinales y angulares, en las cuales, como en los salientes, descansaba toda la grandeza de su honradez?"78_ _. Igualmente, el material con el que se confecciona el altar, la madera incorruptible de Sethim, sirve para expresar la incorruptibilidad del cuerpo y alma de María, es decir, su Virginidad e Inmaculada Concepción, y justificar, como en su momento vimos, su Asunción a los cielos. Así lo expresa el autor:

el altar confeccionado con madera de Setím, ¿no figuraba de un modo muy hermoso la excelencia incorrupta e incorruptible de la bendita Virgen María, en cuanto a la integridad de la mente y el cuerpo? ¿Acaso no fue este el argumento según el cual tras su bendita dormición, Dios no permitió que su cuerpo santo viese la corrupción ${ }^{79}$.

Precisamente, la madera de Sethim es el material que asimismo conforma el Arca de la Alianza, uno de los símbolos que se representan en la bóveda de Mondoñedo (Fig. 14). Este título forma parte de la Letanía Lauretana, cuyas invocaciones son ilustradas en el mundo de la Contrarreforma por diversos autores. Uno de ellos es Francisco Xavier Dornn, en cuyo texto explicativo ofrece un comentario muy próximo al que acabamos de leer ${ }^{80}$. Pero el arca no sólo glosa la pureza de María, sino también su papel como Madre de Dios, pues como indica san Ambrosio: el arca contenía las tablas del testamento, María albergó al

\footnotetext{
76 José de Jesús María, Historia de la Virgen María, Amberes, Francisco Canisio, 1651.

77 Jan DAvid, Pancarpium marianum..., págs. 153-154.

78 Jan DAvid, Pancarpium marianum..., pág. 153.

79 Jan DAVID, Pancarpium marianum..., pág. 153.

${ }^{80}$ Francisco Xavier Dornn, Litaniae Lauretanae ad Beatae Virginis, caelique Reginae Mariae, honorem, et gloriam prima vice in Domo Lauretana a sanctis angelis decantatae, postea ab Ecclesia Catholica, Augustae Vindelicorum, sumptibus Joannis Baptistae Burckhart, 1758, pág. 39 (facsímil de la edición española: Fr. X. Dornn, Letanía lauretana Madrid, Rialp, 1978, pág. 87).
} 
heredero del testamento divino [...] el arca contenía la voz que Dios promulgó, María albergaba el Verbo de Dios eterno ${ }^{81}$.

Este rol se significa igualmente a través del Pozo de Aguas vivas (Fig. 14) y así lo expresa Jan David: “¡Oh [Dios], singular tesoro de aguas vivas, que nos diste en la sacrosanta madre de tu querido hijo! Dios, como eres generoso, en este mismo pozo de aguas vivas la hallamos" ${ }^{22}$. Por tanto, como Madre de Dios, María es pozo de aguas vivas, condición que al mismo tiempo le permite repartir esas aguas entre los devotos, es decir, distribuir, como mediadora, las gracias celestiales entre los fieles.

La mediación de María queda asimismo expresada a través del título Puerta del Cielo (Fig. 15), figura que no sólo ejemplifica la distribución de bienes Todos los días nos entran por ella nuevos y grandes beneficios, y abundantes tesoros de gracias [...] María, por cuya intercesión distribuye Dios sus favores con abundancia a todos los hombres ${ }^{83}$-, sino que alude también a otras facetas de su mediación: María media al convertirse en el vehículo para la venida de Cristo al mundo - Este divino Maná, Cristo, entró en el mundo por la puerta María ${ }^{84}$ - y al cooperar con Él en el proceso de Redención — siguiendo con la misma metáfora, la Virgen es la Corredentora que abre las puertas que Eva había cerrado: Esta puerta celeste, oh Eva, para nosotros la cerraste en el Paraíso, pero tú, oh María, la has abierto ${ }^{85}$.

Esta labor corredentora de la Virgen, pese a iniciarse en el mismo momento de la Encarnación, alcanza su punto culmen en la Pasión de su Hijo, dado que se considera que ella también participa del sacrificio a favor de los hombres a través de la compasión, es decir, padeciendo en su alma el mismo dolor que Cristo sufre en su cuerpo. Una de las metáforas que expresa la perseverancia de María a los pies del madero es el ciprés (Fig. 15), motivo incluido entre los emblemas que A. Ginther dedica a la Mater Dolorosa, cuyo comentario reza:

que el ciprés es un árbol bellísimamente provisto, que se levanta altísimamente hacia la copa, que en ninguna época del año pierde su vigor, que no cede a las injurias ni de los vientos ni de las tempestades [...] He aquí un símbolo preclaro de la afligidísima

\footnotetext{
${ }^{81}$ Nicolás de la IgLesia, Flores de Miraflores. Hyeroglificos Sagrados, Verdades figuradas, sombras verdaderas del mysterio de la Inmaculada Concepción de la Virgen y Madre de Dios, María Señora Nuestra, Burgos, Diego de Nieva y Murillo, 1659.

82 Jan David, Pancarpium marianum..., pág. 56.

${ }^{83}$ Francisco Xavier DoRnN, Letanía lauretana..., pág. 89.

${ }^{84}$ Francisco Xavier Dornn, Letanía lauretana..., pág. 89.

85 Jan DAvid, Pancarpium marianum..., pág. 192.
} 
Virgen, siempre perseverante bajo la cruz del Hijo con todas las angustias $^{86}$.

Pero María no sólo contribuye a la Salvación de los hombres al favorecer la reapertura del Paraíso, sino que los auxilia mientras permanecen en el mundo para que efectivamente accedan a él. La Virgen ejerce entonces como la torre de David (Fig. 15), en tanto y cuanto defiende a los fieles contra los enemigos, visibles e invisibles: Así a ti, o beatísima Virgen, protectora nuestra, torre de David, declaramos que eres nuestro refugio en el cual nos gloriamos [...] María, como torre te levantas para nosotros en la casa de David ${ }^{87}$.

Igualmente, la fortaleza de la que María hace gala le permite no sólo defender a los hombres, sino vencer ella misma al pecado en el momento de su concepción — Inmaculada — y durante toda su vida — Virginidad—. Esta pureza corporal y espiritual se significa a través de otra torre a la que también puede referirse la mindoniense, la torre de marfil, dado que el marfil o diente de elefante es símbolo de muchas virtudes. El marfil, con su admirable y hermosa blancura, denota la incomparable virginidad de María ${ }^{88}$.

Asimismo, esta prerrogativa puede ser plasmada a través de otro motivo que en la catedral sostiene uno de los angelotes (Fig. 19): el espejo, pues, de la misma forma que los rayos del Sol inciden en él y se proyectan fuera sin dañarlo, Cristo — como Sol de Justicia—, se encarnó en el vientre de su madre y nació de ella sin lesionar su virginidad ${ }^{89}$.

La propia María es también comparada con el astro rey —Electa ut sol-, con la luna —Pulchra ut luna - y con la estrella — Stella maris, Stella matutina, Aurora consurgens - , símbolos que, al igual que los anteriores, han dado lugar a múltiples interpretaciones en relación con sus prerrogativas. No obstante, su presencia en Mondoñedo, al disponerse encima de la Asunción (Fig. 13), creemos que debe relacionarse con el cántico con que los Ángeles reciben a la Virgen en su llegada a los cielos, el cual no es otro que estos versículos del Cantar de los Cantares: “¿Quién es ésta que sube toda pura, surgiendo como la aurora, hermosa como la luna y escogida como el sol?"90.

\footnotetext{
${ }^{86}$ Anton GinTHER, Mater amoris et doloris, quam Christus in cruce moriens omnibus ac singulis suis fidelibus in matrem legavit, Ecce Mater Tua, Augusta Vindelicorum, sumptibus Martini Veith, 1711, págs. 361-362.

87 Jan DAVID, Pancarpium marianum..., págs. 112-113.

${ }^{88}$ Francisco Xavier Dornn, Letanía lauretana..., pág. 83.

${ }^{89}$ Francisco Xavier Dornn, Letanía lauretana..., pág. 43.

90 San Juan Damasceno, Homilía I de la Asunción, cit. en Guillermo Pons, Textos marianos..., pág. 281.
} 


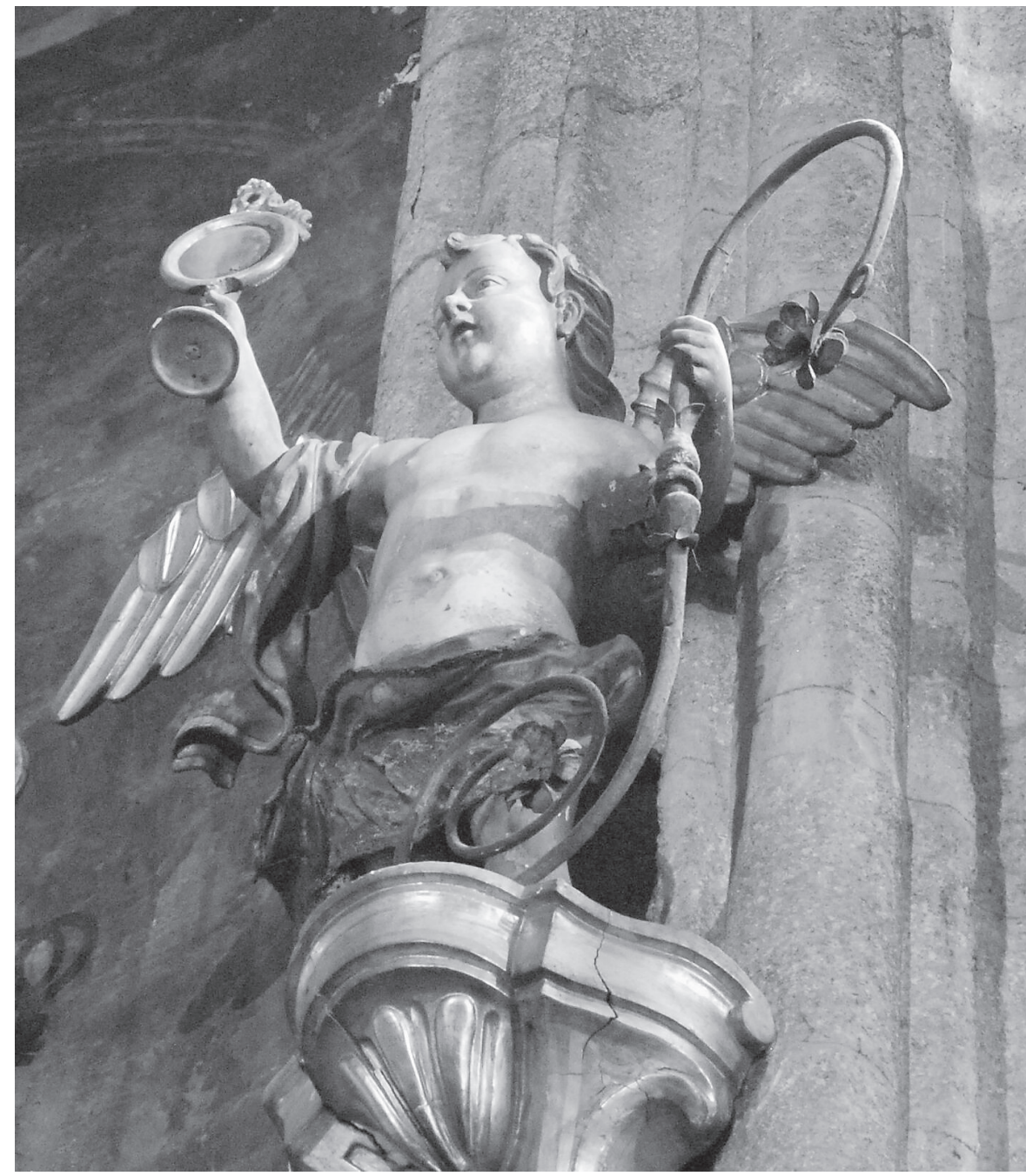

Fig. 19

Ángel con espejo, lateral del retablo mayor.

Se considera que es en los Cielos en donde María, convertida en Reina y Señora de todo lo creado, puede hacer más efectiva su mediación, auxiliando a los hombres, distribuyéndoles las gracias e intercediendo por ellos ante Dios. Este papel protector de la Virgen se ha puesto en relación con la actitud de la Madre de Tobías en el juicio de Salomón, escena que, como vimos, se muestra en el crucero de Mondoñedo (Fig. 3). En este sentido, Francisco Xavier Dornn, en el comentario a la invocación Auxilio de los cristianos, explica: 
Pero si se pregunta que desde quando recibió Maria a los Christianos en su protección, se responderá que desde que Christo constituyó desde la Cruz a María por Madre de san Juan: en san Juan la hizo Madre de todos los Christianos. Y a la verdad, mayor cuidado tiene esta madre, respecto de nosotros los Christianos, que la otra madre cuidadosa, respecto de su hijo Tobías. Porque assí como en el juicio de Salomón no permitió la que era Madre verdadera que su hijo fuesse hecho pedazos; assí María no permite se haga mal alguno a sus hijos los Christianos ${ }^{91}$.

También en clave de intercesión y auxilio creemos que deben interpretarse las Mujeres Fuertes que flanquean el presbiterio (Figs. 16-17), dado que, al margen de otras muchas virtudes que encarnan y que se consideran tipos de las de María, las escenas aquí escogidas hacen hincapié en la ayuda que estas mujeres prestaron: a sus pueblos — Gael matando a Sísara, Judith a Holofernes y Débora dictando justicia y ofreciendo consejo- y Abigail a su marido, al mediar en su favor ante David. Son numerosísimos los textos en que estas figuras bíblicas se ponen en relación con la Virgen; simplemente por citar algunos:

Jael y Judith manifestaron el grande poder de su brazo [...] Pero María se muestra mucho más poderosa, pues mantiene con sus brazos al que mantiene todo el mundo y abrazó en sí a Dios inmenso y omipotente [...] y así no es maravilla que sea tan poderosa ${ }^{92}$;

La segunda [letra] deste nombre de María es A y sinifica que fue figurada en Abigail [...] [la injuria de su marido a David] entendiéndola Abigail, le salió al camino, adornada ricamente y ofrecióle grandes dones, y hablóle con humildes palabras, y con esto se aplacó David. Por David es entendido Dios, ayrado y enojado con el rústico y sayaguesco linage humano, por la ingratitud que tuvo Adán cabeça de todos los mortales [...] Mas salióle al encuentro la beatísima siempre Virgen María, adornada con muchas virtudes y limpieza de coraçón... ${ }^{93}$;

\footnotetext{
${ }^{91}$ Francisco Xavier Dornn, Letanía lauretana..., op. cit., pág. 99.

92 Francisco Xavier Dornn, Letanía lauretana..., op. cit., pág. 61.

93 Antonio Navarro, Abecedario Virginal de excelencias del Santíssimo nombre de María, Madrid, en casa de Pedro Madrigal, 1604, fol. 40v.
} 
EL PROGRAMA ICONOGRÁFICO DEL PRESBITERIO Y CRUCERO DE LA CATEDRAL DE MONDOÑEDO (1769-1773) Y LA RECONSTRUCCIÓN DE LA "PRUEBA PERDIDA"

Era Débora una muger Profeta. Era Jurispridenta. Governava regía y dava leyes al Pueblo de Israel; y por esto acudían a ella en sus consultas y dificultades. Era una Señora, que favorecía al Pueblo con empleos de Madre [...] Fue Débora símbolo y representación de la Virgen María [...] Es Madre de misericordia de todos los fieles. Madre, a quen Dios ha dotado de prudencia, de consejo y de fortaleza, para que a su dirección se goviernen los Reyes y príncipes de su Iglesia... ${ }^{94}$.

En el terreno artístico, también es habitual encontrar a estas mujeres en espacios vinculados a la Madre de Dios; sirvan como ejemplo la Capilla de la Inmaculada en la Cartuja de Miraflores ${ }^{95}$, el camarín de la Virgen en el Monasterio de Guadalupe, o la serie grabada por Anton II Wierix para ilustrar la Salve $e^{96}$. Lo mismo sucede en el Escorial, en concreto, en las pechinas de la bóveda del Triunfo de las Vírgenes, en donde las concomitancias respecto a Mondoñedo vuelven a ser notorias:

En la segunda estancia se ve Débora, juez y profetisa del Pueblo de Dios, de gran belleza, con bastón en una mano, y un libro abierto en la otra, sentada al pie de una frondosa palma, sitio de su judicatura, la que venció con Barac, General del Exército de Israel, al de Jabín, Rey de Canaan, quando fugitivo su General Sísara vino a morir a manos de la hermosa Jael, que con el Maço y Clavo, con que en su tentorio le atravesó las sienes, está aquí pintada en compañía de Débora. A ésta le da el libro de los Juezes (que es el que tiene en la mano) el título de Madre de Israel, por esta vitoria; y a la valerosa Jael, el de Bendita entre las mugeres: y ya se ve con quanta superioridad se deben a María Santíssima essos elogios, por sus gloriosos triunfos [...] Desde esta Pechina, o estancia, a la que se sigue, ocupan el espacio con hermosura grande [...] Abigail [...] En la otra estancia, que es la última de las pechinas, está la animosa Judith con su Abra, o Criada, empuñada la Espada, la

\footnotetext{
94 Juan Bautista de Murcia, Clarín evangélico panegyrico, Barcelona, Imprenta de Carlos Sapera, 1753, pág. 167.

95 Al respecto, véase Patricia Andrés GonzÁlez, "Las pinturas barrocas de la capilla de la Virgen de Miraflores (Burgos)", en Jesús María Parrado del Olmo y Fernando Gutiérrez Baños (coords.), Estudios de historia del arte: homenaje al profesor De la Plaza Santiago, Valladolid, Universidad de Valladolid, Secretariado de Publicaciones e intercambio Editorial, 2009, págs. 63-70.

96 Anton II Wierix, Salve Regina, Antuerpia, 1598.
} 
punta al suelo, con despejo bizarro, y la cabeça de Olofernes a sus pies, que degolló en defensa del Pueblo de Israel y suya... ${ }^{97}$.

Hasta ahora, hemos venido hablando de las prerrogativas de la Virgen y, entre ellas, de la mediación que acomete entre Dios y los hombres. Ahora bien, ¿qué deben hacer estos para conseguir su ayuda? O dicho con otras palabras: ¿cómo pueden actuar como verdaderos devotos de María y conseguir la Salvación? Si atendemos a los textos de época, estos proclaman quan agradable le es a esta Señora la limpieza [del ánima], y quan buen medio es el procurarla para alcançar la devoción desta Santíssima Virgen ${ }^{98}$.

Precisamente, cómo lograr la limpieza del alma es posiblemente la lectura que subyace tras las alegorías del retablo de Mondoñedo (Fig. 11), aunque, para comprenderlas en su totalidad, es necesario tener presente una cosa: en el mundo de la Contrarreforma, la gran obsesión de los hombres es alcanzar la Salvación y, en relación con ello, la Iglesia Católica asume el ideal Vive bien, para morir bien. Morir bien significa morir en gracia; vivir bien supone despreciar todo lo relacionado con el mundo y centrarse en conseguir la perfección del espíritu. Este proceso de Contemptus mundi y perfeccionamiento espiritual se denomina Ascética. Durante la Ascesis, los hombres cuentan con una serie de instrumentos que los ayudan a purificarse: actos piadosos, mortificación, oración y meditación; valiéndose de ellos, inician un largo camino que tendría como objetivo último la Mística, es decir, la unión y comunicación directa con Dios ${ }^{99}$.

Durante los siglos XVII y XVIII surgen numerosas obras destinadas a narrar este crecimiento espiritual del alma, que se suele dividir en tres fases: la vía purgativa, que coincide con la Ascesis; la vía iluminativa o contemplativa y la vía unitiva, que equivale a la Mística. Entre estas obras, destacan especialmente dos, la Schola Cordis $^{100}$ y el Pia Desideria ${ }^{101}$, cuyos grabados se copiaron en numerosas iglesias, conventos y monasterios, prueba evidente de su repercusión ${ }^{102}$. Entre las ideas que expresan, hay algunas que se repiten hasta la saciedad:

\footnotetext{
${ }^{97}$ Francisco de los Santos, Descripción...., fols. 40r.-40v.

${ }^{98}$ Pedro Hernández, Tratado de las festividades..., pág. 16.

99 Santiago Sebastián, Contrarreforma y Barroco..., págs. 65-66.

${ }^{100}$ Benedictus van HAEFTEN, Schola cordis sive aversi à Deo cordis ad eumdem reductio, et instructio, Antuerpiae, apud ioannem Meursium et Hieronimum Verdussium, 1629.

${ }^{101}$ Hugo Hermann, Pia Desideria lib. III ad Urbanum VIII, Antuerpiae, apud Henricum Aertssens, 1624.

${ }^{102}$ Entre muchos otros ejemplos, los grabados del Pia Desideria sirven de fuente para los lienzos del coro de Katharinenheerd auf Eiderstedt (Ingrid HöPEL y Ulrich y Kuder, Mundus Symbolicus I. Emblembücher aus der Sammlung Wolfgang J. Müller in der Universitätbibliothek Kiel, Kiel, Verlag Ludwig, 2004, págs. 63-65), para las pinturas de la bóveda del presbiterio de la Capilla viseense de Nuestra Señora de la Esperanza (Carme López CALDERón, "La emblemática como ins-
} 
EL PROGRAMA ICONOGRÁFICO DEL PRESBITERIO Y CRUCERO DE LA CATEDRAL DE MONDOÑEDO (1769-1773) Y LA RECONSTRUCCIÓN DE LA "PRUEBA PERDIDA"

Primera, la necesidad de ser humildes:

Considera lo tercero, que no dixo Christo, el que fuere humillado; sino el que se humillare a sí, será ensalzado: con que es preciso, que te humilles a ti, que te deprimas, y no desdeñes el propio abatimiento. La humillación (dice S. Bernardo) es camino de humildad [...] Así pues, si queremos subir hacia arriba, vamos hacia baxo por la sumisión y humilde abatimiento ${ }^{103}$.

Segunda, la necesidad de oración: Considera lo quarto, que ningún sacrificio aplaca más aquella soberana magestad que el sacrificio del corazón [...] Y S. Gregorio [dize]: No atiende Dios a la vozes del que suplica, sino al corazón del que ora ${ }^{104}$.

Tercera, la necesidad de penitencia:

También el corazón sucio, inútil para obras de piedad, tupido al influxo de la gracia (que no entra en corazón sujeto a culpa) si se macea por la penitencia y dolor del ánimo, se hará tan blanco y tan puro papel, que en él escriba su ley Dios [...] Por tanto debe qualquiera estimar la penitencia y contrición, quanto estima la salud de su alma, y la felicidad eterna ${ }^{105}$.

Cuarta, la necesidad de abandonar los engaños mundanos y centrarse en la única Verdad, Dios:

trumento...), para los azulejos de la Casa de la Hermandad de la Iglesia de Santa Cruz en Santarém y de la Casa del Capítulo en el antiguo Convento de Santa Marta de Lisboa (João Pedro Monteiro, "Os Pia Desideria, uma fonte iconográfica da azulejaría portuguesa do século XVIII", Azulejo, 3/7 (1995-1999), págs. 61-70) y para las pinturas murales del Claustro de los Naranjos en el monasterio de Santa Catalina de Arequipa, Perú (Rafael García Mahiques, "Gemidos, deseos y suspiros. El programa místico de Santa Catalina de Arequipa", Boletín del Museo e Instituto Camón Aznar, 48-49 (1992), págs. 83-114). En este último ejemplo, se utilizan también imágenes tomadas del Schola Cordis, igualmente mimetizadas en la bóveda de la Iglesia del Convento de San Francisco de Castelo Branco en Covilha (Maria do Carme Mendes, Pintura Barroca e Emblema: imagética da Escola do Coração no tecto da capela-mor da Igreja de Nossa Senhora da Conceição, na Covilhã (1675-1725), dissertação para obtenção do grau de Mestre em Arte, Património e Teoria do Restauro, FLUL, Lisboa, 2009).

${ }^{103}$ Benedictus Van Haeften (Diego de Mecolaeta trad.), Escuela del corazón, Tomo I. Contiene los libros I y II, Madrid, por D. Blas Román, 1791, págs. 191-193.

${ }^{104}$ Benedictus Van Haeften (Diego de Mecolaeta trad.), Escuela del corazón, Tomo I..., pág. 239. ${ }^{105}$ Benedictus Van Haeften (Diego de Mecolaeta trad.), Escuela del corazón, Tomo II. Contiene los libros III y IV, Madrid, por D. Blas Román, 1791, págs.182-186. 
[San Gregorio Nacianceno dice] que el alma se deleita en sola la contemplación del verdadero bien, está dormida a todo gusto sensual: ya dormecidos todos los movimientos corpóreos, percibe con la mente pura y clara, como en una divina vigilia, lo que Dios la manifiesta ${ }^{106}$.

En realidad, la Ascética y la Mística son dos ideales que, si bien impregnan totalmente la espiritualidad contrarreformista, en España se desarrollan ya en el siglo XVI, de la mano de figuras como santa Teresa, san Juan de Ávila, fray Luis de León, fray Luis de Granada o san Juan de la Cruz. Precisamente, este último escribe las Obras espirituales que encaminan a una alma a la más perfecta unión con Dios, en donde encontramos una advertencia que, estando en línea con los fragmentos que acabamos de leer, enlaza perfectamente las cuatro alegorías que se representan en Mondoñedo:

Que no ai poder sobre la tierra, que se compare a este del Demonio, que fue hecho de suerte que a ninguno temiesse. Esto es, ningún poder humano se podrá comparar con el suyo, y assí solo el Divino basta para poderle vencer, y sola la luz Divina, para poderle entender sus ardides: por lo quel, el alma, que huviere de vencer su fortaleça, no podrá sin Oración, ni sus engaños podrá entender sin humildad y sin mortificación ${ }^{107}$.

\section{CONCLUSIÓN FINAL: LA POSIBLE "PRUEBA PERDIDA"}

A tenor de lo expuesto, parece claro que el programa iconográfico de la Catedral de Mondoñedo debe ser interpretado a partir de las enseñanzas que la Iglesia Contrarreformista predica en relación a los fieles y la Virgen María.

Respecto a los primeros, y conforme a la recomendación de vivir bien para morir bien, las alegorías del retablo explicitan cómo, mediante la humildad, oración, penitencia y mortificación, estos pueden conocer los engaños del mundo, abandonarlos y purgarse, es decir, limpiar su alma.

La limpieza del alma es el requisito para que los hombres avancen por el camino correcto que los conduce a Dios, pero también para que alcancen la devoción de aquella que, como más excelsa Mediadora y Corredentora, los ayu-

\footnotetext{
${ }^{106}$ Benedictus Van HaEfTen (Diego de Mecolaeta trad.), Escuela del corazón, Tomo II..., págs. 157-158.

${ }^{107}$ San Juan de la Cruz, Obras espirituales..., pág. 290.
} 
dará a lo largo de este progreso: María. En este sentido, como recuerdan la talla y la pintura mindonienses, la Virgen, siendo la Madre de Dios (sibilas, Arca de la Alianza), permaneciendo pura (Torre de marfil, Espejo sin mancha) y una vez Asunta a los Cielos (¿Quién es ésta que sube toda pura, surgiendo como la aurora, hermosa como la luna y escogida como el sol?), les brinda su auxilio para lograr la Salvación: los ayuda como Corredentora (Puerta del Cielo, Ciprés), como Intercesora (Judith, Jael, Débora, Abigail), como Distribuidora de gracias (Pozo de aguas vivas, fuente rebosante de agua) y como protectora contra los enemigos (Torre de David, Josafat, Josías, Ezequías, Salomón). Pero también como modelo de comportamiento: María es el espejo en el que mirarse para, imitando sus Virtudes (cardinales y teologales), acceder a la gloria eterna:

"Y passados algunos días en estos affectos y disposición, el Altíssimo me declaró, cómo aquella escala [de Jacob] era la vida de la Santísima Virgen, sus virtudes y Sacramentos. Y su Magestad me dijo: Quiero, esposa mía, subas por esta escala de Jacob y entres por esta puerta de el Cielo a conocer mis atributos y contemplar mi Divinidad: sube pues, y camina, sube por ella a mí [...] Atiende, y meditando estas virtudes trabaja por imitarlas" 108 .

\section{BIBLIOGRAFÍA}

Agreda, María de Jesús, Mystica ciudad de Dios, milagro de su omnipotencia, y abysmo de la gracia, Amberes, Hermanos de Tournes de León de Francua, 1736.

Andrés González, Patricia, "Emblemas marianos de la Capilla de la Virgen en la Cartuja de Burgos. El modelo pintado y su repercusión iconográfica”, Boletín del Seminario de Estudios de Arte y Arqueología: BSAA, 69-70 (2003-2004), págs. 383-409.

Andrés González, Patricia, "Las pinturas barrocas de la capilla de la Virgen de Miraflores (Burgos)", en Jesús María Parrado del Olmo y Fernando Gutiérrez Baños (coords.), Estudios de historia del arte: homenaje al profesor De la Plaza Santiago, Valladolid, Universidad de Valladolid, Secretariado de Publicaciones e intercambio Editorial, 2009.

Barón y Arín, Jaime, Luz de la fe y de la Ley, Barcelona, Imprenta de Teresa Piferrer, 1735.

Bitterli, Dieter, Der Bilderhimmel von Hergiswald: der barocke Emblemzyklus der Wallfahrtskirche Unserer Lieben Frau in Hergiswald bei Luzern, seine Quellen, sein mariologisches Programm und seine Bedeutung, Basel, Wiese, 1999.

Cal Pardo, Enrique, "Sacristía y Custodia de la Catedral basílica de Mondoñedo", Estudios Mindonienses, 3 (1987), págs. 549-570.

\footnotetext{
${ }^{108}$ María de Jesús Agreda, Mystica ciudad de Dios, milagro de su omnipotencia, y abysmo de la gracia, Amberes, Hermanos de Tournes de León de Francua, 1736, pág.12.
} 
Cal Pardo, Enrique, "El voto inmaculista en la catedral de Mondoñedo", Estudios Mindonienses, 8 (1992), págs. 371-417.

Cal Pardo, Enrique, Episcopologio mindoniense, Santiago de Compostela, Consejo Superior de Investigaciones Científicas, Instituto de Estudios Gallegos Padre Sarmiento, 2003 (Anejos de Cuadernos de Estudios Gallegos, 28).

David, Jan, Pancarpium marianum septemplici titulorum serie distinctum, Antuerpiae, ex officina Plantiniana, apud Balthasarem et Ioannem Moretos fratres, 1607.

Dornn, Francisco Xavier, Litaniae Lauretanae ad Beatae Virginis, caelique Reginae Mariae, honorem, et gloriam prima vice in Domo Lauretana a sanctis angelis decantatae, postea ab Ecclesia Catholica, Augustae Vindelicorum, sumptibus Joannis Baptistae Burckhart, 1758.

Dornn, Francisco Xavier, Letanía lauretana, Madrid, Rialp, 1978.

Escalera Pérez, Reyes, "Emblemática mariana. Flores de Miraflores de Fray Nicolás de la Iglesia”, Imago. Revista de Emblemática y Cultura Visual, 1 (2009), págs. 45-63.

Fernández Castiñeiras, Enrique, "El lenguaje pictórico mariano de la capilla mayor de Mondoñedo", Adaxe, 7 (1991), págs. 43-51.

Fernández Castiñeiras, Enrique y Monterroso Montero, Juan Manuel, "Ecclesia, Domus et Mullier. Fundamentos iconográficos para el estudio de las pinturas de José de Terán en la catedral de Mondoñedo", en Francisco Singul (dir.), Rudesindus. La tierra y el templo, Santiago de Compostela, Xunta de Galicia, Consellería de Innovación e Industria, S.A. de Xestión do Plan Xacobeo, 2007, págs. 187-205.

Fiores, Stefano de y Meo, Salvarore (dir.), Nuevo diccionario de mariologías, Madrid, San Pablo, 1988.

García, Francisco, Cinco sermones del Santissimo y Dulcissimo nombre de María, Madrid, por Juan García Infançon, 1681.

García Iglesias, José Manuel, "La capilla mayor y el coro de la catedral de Mondoñedo a partir de 1769", Letras Galegas en Deusto. Dez anos de estudios galegos, 1991-2001, Cátedra de Estudios Galegos, Facultad de Filosofía y Letras, Universidad de Deusto, 2001, págs. 191-210.

García Mahiques, Rafael, "Gemidos, deseos y suspiros. El programa místico de Santa Catalina de Arequipa”, Boletín del Museo e Instituto Camón Aznar, 48-49 (1992), págs. 83-114.

Ginther, Anton, Mater amoris et doloris, quam Christus in cruce moriens omnibus ac singulis suis fidelibus in matrem legavit, Ecce Mater Tua, Augusta Vindelicorum, sumptibus Martini Veith, 1711.

Gombrich, Ernest: Imágenes simbólicas, Madrid, Alianza editorial, 1983 [1972].

González García, Miguel Ángel y Hervella Vázquez, José, "Emblemática y Mariología: el santuario de Nuestra Señora de las Ermitas y los Hieroglíficos Sagrados de Fray Nicolás de la Iglesia”, en Sagrario López Poza (ed.), Literatura emblemática hispánica. Actas del I Simposio Internacional, Coruña, Universidade da Coruña, Servicio de Publicaciones, 1996, págs. 501-514.

Hermann, Hugo, Pia Desideria lib. III ad Urbanum VIII., Antuerpiae, apud Henricum Aertssens, 1624 . 
EL PROGRAMA ICONOGRÁFICO DEL PRESBITERIO Y CRUCERO DE LA CATEDRAL DE MONDOÑEDO (1769-1773) Y LA RECONSTRUCCIÓN DE LA "PRUEBA PERDIDA"

Hernández, Pedro, Tratado de las festividades de la Santíssima Virgen María, Madre de Dios y Señora Nuestra, Madrid, Luis Sánchez, 1618.

Höpel, Ingrid y Kuder, Ulrich, Mundus Symbolicus I. Emblembücher aus der Sammlung Wolfgang J. Müller in der Universitätbibliothek Kiel, Kiel, Verlag Ludwig, 2004.

Iglesia, Nicolás de la, Flores de Miraflores. Hyeroglificos Sagrados, Verdades figuradas, sombras verdaderas del mysterio de la Inmaculada Concepción de la Virgen y Madre de Dios, María Señora Nuestra, Burgos, Diego de Nieva y Murillo, 1659.

José de Jesús María, Historia de la Virgen María, Amberes, Francisco Canisio, 1651.

Juan de la Cruz, Santo, Obras espirituales que encaminan a una alma, a la más perfecta unión con Dios, en transformación de amor, Sevilla, por Francisco de Leesdael, 1703.

Loda, Angelo, "Il sangue del Redentore. Testimonianze figurative eucarístico-sacramentali nella diocesi di Brescia", Brixia Sacra. Memorie Storiche della Diocesi di Brescia, 1-2 [1999], págs. 52-70.

López Calderón, Carme, Oración perpetua a la Madre de Dios: una aproximación iconográfica a la Capilla de Nuestra Señora de los Ojos Grandes, con apéndice de Inocencio Portabales, Tesis de Licenciatura inédita, Santiago de Compostela, 2011.

López Calderón, Carme, "La emblemática como instrumento devocional: la Capilla de Nossa Senhora da Esperança en Abrunhosa (Viseu, Portugal)", en Palabras, símbolos, emblemas. Las estructuras gráficas de la representación. Actas del VIII Congreso Internacional de la Sociedad Española de Emblemática, en prensa.

López Vázquez, José Manuel, "Los retablos mayores: homilía contrarreformista y propaganda monástica", en Opus Monasticorum. Patrimonio, Arte, Historia y Orden, Santiago de Compostela, Xunta de Galicia, Consellería de Cultura, Comunicación Social y Turismo, Dirección General de Patrimonio Cultural, 2005, págs. 215-279.

Mendes, Maria do Carme, Pintura Barroca e Emblema: imagética da Escola do Coração no tecto da capela-mor da Igreja de Nossa Senhora da Conceição, na Covilhã (1675-1725), dissertação para obtenção do grau de Mestre em Arte, Património e Teoria do Restauro, FLUL, Lisboa, 2009.

Monteiro, João Pedro, "Os Pia Desideria, uma fonte iconográfica da azulejaría portuguesa do século XVIII", Azulejo, 3/7 (1995-1999), págs. 61-70.

Morales Folguera, José Miguel, Las sibilas en el arte de la Edad Moderna, Europa mediterránea y Nueva España, Málaga, Servicio de Publicaciones de la Universidad de Málaga, 2007.

Murcia, Juan Bautista de, Clarín evangélico panegyrico, Barcelona, Imprenta de Carlos Sapera, 1753.

Navarro, Antonio, Abecedario Virginal de excelencias del Santíssimo nombre de María, Madrid, en casa de Pedro Madrigal, 1604.

Palomino, Antonio, El museo pictórico y escala óptica, Tomo segundo, práctica de la pintura, Madrid, Viuda de Juan García Infançon, 1724.

Panofsky, Erwin, Estudios sobre iconología, Madrid, Alianza, 1972.

Pons, Guillermo, Textos marianos de los primeros siglos. Antología patrística, Madrid, Ciudad Nueva, 1994. 
Porreño, Baltasar, Oráculos de las doçe Sibilas. Profetisas de Christo nro. Señor entre los Gentiles, Cuenca, por Domingo de la Yglesia, 1621.

Réau, Louis, Iconografia de la Biblia. Antiguo Testamento, tomo 1, vol. 1, Barcelona, Ediciones del Serbal, 1996.

Réau, Louis, Iconografia del arte cristiano. Iconografía de los santos G-O, tomo 2, vol. 4, Barcelona, Ediciones del Serbal, 1997.

Réau, Louis, Iconografia del arte cristiano. Iconografía de los santos P-Z, tomo 2, vol. 5 , Barcelona, Ediciones del Serbal, 1998.

Ribadeneyra, Pedro de, Flos Sanctorum, de las vidas de los santos, tomo primero. Contiene la vida de Christo y su Santíssima Madre, y de los Santos incluidos en los meses de Enero, Febrero, Marzo y Abril, Barcelona, Imprenta de Juan Piferrer, 1734.

Ripa, Cesare, Iconología, tomo 1, Madrid, Ediciones Akal, 1987 [1613].

Ripa, Cesare, Iconología, tomo 2, Madrid, Ediciones Akal, 1987 [1613].

Santos, Francisco de los, Descripción del Real Monasterio de San Lorenzo de el Escorial, única maravilla del mundo, Madrid, Imprenta de Juan García Infançon, 1698.

Santos San Cristóbal, Sebastián, La catedral de Mondoñedo, Lugo, Servicio de Publicaciones de la Diputación Provincial, 1989.

Sebastián, Santiago, Contrarreforma y Barroco. Lecturas iconográficas e iconológicas, Madrid, Alianza Editorial, 1985.

Sebastián, Santiago, Iconografía e Iconología del arte novohispano, México, Grupo Azabache, 1992.

Sernani, Giorgio, Los dogmas de María. Las piedras más preciosas de su corona, Buenos Aires, Publicación de la Orden de María Reina, 2002.

Smet, Joseph Jean de: Mensis marianus, Gandae, typis Fratrum J. et H.Vander Schelden, 1858.

Vallejo, José Ignacio, Vida del Señor San Josef dignísimo esposo de la Virgen y padre putativo de Jesús, Cesena, Imprenta de Gregorio Biasini, 1779.

Van Haeften, Benedictus, Schola cordis sive aversi à Deo cordis ad eumdem reductio, et instructio, Antuerpiae, apud ioannem Meursium et Hieronimum Verdussium, 1635.

Van Haeften, Benedictus (Mecolaeta, Diego de, trad.), Escuela del corazón, Tomo I. Contiene los libros I y II, Madrid, por D. Blas Román, 1791.

Van Haeften, Benedictus (Mecolaeta, Diego de, trad.), Escuela del corazón, Tomo II. Contiene los libros III y IV, Madrid, por D. Blas Román, 1791.

Von Erffa, Hans Martin, "Das Programm der Westportale des Pisaner Domes", Mitteilungen des Kunsthistorischen Institutes in Florenz, 12 (1965), pp. 55-106.

Ximenez, Andrés, Descripción del Real Monasterio de San Lorenzo del Escorial, su magnífco templo, panteón y palacio, Madrid, Imprenta de Antonio Marín, 1764 